\title{
Geochemical characteristics of the Sumikawa geothermal system, northeast Japan
}

\author{
Akira Ueda ${ }^{1}$, Yasuhiro Kubota ${ }^{1}$, Hisao Katoh ${ }^{2 *}$, \\ KAZUYOSHI HataKeYAMA ${ }^{2}$ and OSAMU Matsubaya ${ }^{3}$ \\ Central Research Institute, Mitsubishi Materials Corporation, \\ 1-297 Kitabukuro-cho, Omiya, Saitama, 3301, \\ Geothermal Energy Development Department, Mitsubishi Materials Corporation, \\ 60-2 Dounoue, Kazuno, Akita, 018-512, \\ and Research Institute of Natural Resourses, Mining College, Akita University, \\ Tegata Gakuen-cho, Akita, $010^{3}$, Japan
}

(Received January 15, 1991; Accepted August 21, 1991)

\begin{abstract}
Chemical and isotopic data are summarized for fluids from newly drilled wells in the Sumikawa geothermal system, northern Honshu, Japan, and the geochemical characteristics of the reservoir are discussed. The fluids are mainly of the $\mathrm{Na}-\mathrm{Cl}$ type with a near neutral $\mathrm{pH}$, and measured temperatures in wells often exceed $300^{\circ} \mathrm{C}$. The total dissolved salt concentration is low $(<3000 \mathrm{mg} / \mathrm{kg})$, less than other high temperature geothermal systems in Japan. The chemical and isotopic compositions of the fluids vary from well to well. One well (S-2) produces both acid sulfate-chloride and weakly acid $\mathrm{pH}$ fluids from two different feed zones, with these fluids possibly related to a local magmatic component.

The Sumikawa geothermal waters are diluted by a relatively shallow heated $\left(\sim 200^{\circ} \mathrm{C}\right)$ water that contains sulfate plus bicarbonate but nil chloride. The hydrogen and oxygen isotopic compositions of the total fluid indicate that the fluids are of meteoric origin, with an oxygen isotope shift of less than $2 \%$. The $\mathrm{SO}_{4}$ in the meteoric-dominated neutral $\mathrm{pH}$ waters comes from sulfur in rocks, which is essentially a mixture of supergene and fossil marine $\mathrm{SO}_{4}$. On the basis of the $\mathrm{N}_{2}$, $\mathrm{Ar}$ and $\mathrm{He}$ values in the vapor fraction, the chemical and isotopic variation of the fluids appears to be due to different degrees of minor magmatic contribution of volatiles to the hydrothermal fluid. Despite the meteoric-dominant source of most water, the magmatic contribution of volatiles results in fluids that are relatively immature and out of chemical equilibrium with the host rocks and alteration minerals.
\end{abstract}

\section{INTRODUCTION}

The Sumikawa geothermal system is located on the slope of Mt. Akita-Yake in the Hachimantai volcanic region (Fig. 1). A $50 \mathrm{MWe}$ geothermal power plant is under construction, while a 10 MWe power station was commissioned by Mitsubishi Materials Corporation (MMC) in 1974 at Ohnuma, $1.5 \mathrm{~km}$ east of Sumikawa (Fig. 2). At present, seven wells (S-4, SA-1, SA-2, SA4 , SB-1, SD-1 and SC-1) will be used for production and four wells (S-2, SB-2, SD-2 and SB-3) for reinjection of separated water (Fig. 3).
The Ohnuma-Sumikawa geothermal system has been the subject of geologic and mineralogic studies (Yora et al., 1973, 1977; Kubota, 1979, Sakai et al., 1986). Kubota $(1985,1988)$ suggested that the subsurface temperature is highest to the south due to up flow associated with the Akita-Yake volcanic activities. The convection system in this area appears to have an associated down-flow zone to the north (Fig. 2). At the Sumikawa system, a down flow is postulated by Kubota (1988).

Chemical and isotopic studies have been conducted on thermal waters and fumarolic gases in

*Present address: NEDO, Higashi-Ikebukuro 3-1-1 Toshima, Tokyo, Japan 170. 

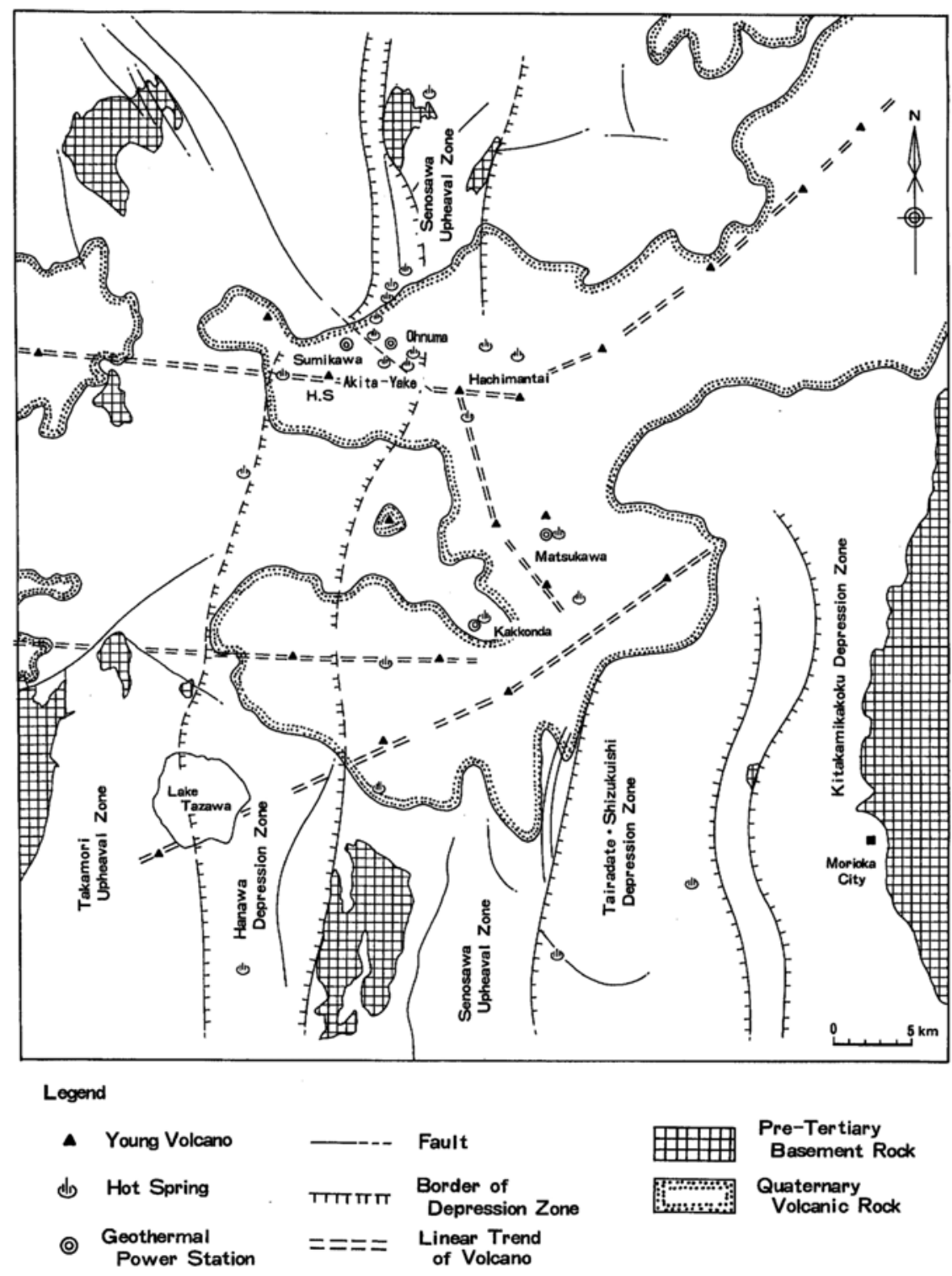

Fig. 1. Tectonic map of Hachimantai volcanic field (after Sakai et al., 1986).

the Hachimantai area (Matsubaya et al., 1975, 1983; Shigeno and Abe, 1987) and on fluids from well S-4, which was drilled prior to 1983 with other S-series wells (S-1, S-2 and S-3). Noda et al. (1987) suggested a mixing model, with several sources for fluids, based on the chemical character of the thermal springs and geothermal wells. They demonstrated that acid $\mathrm{Cl}-\mathrm{SO}_{4}$ type fluid is associated with volcanic gas that originates from beneath Mt. Akita-Yake, to the southwest, while neutral $\mathrm{Na}-\mathrm{Cl}$ type fluid of low salinity and a high $\mathrm{B} / \mathrm{Cl}$ ratio discharges to the north. In the Ohnuma area, the composition of production fluids has been monitored after the start of operation of the power station. Increases in the chloride concentration and $\delta^{18} \mathrm{O}$ are due to return of separated water injected into the reservoir (Kubota et al., 1989). Based on these variations, the mass of the mixing box was estimated to be $3 \times 10^{9} \mathrm{~kg}$ (Kubota and Matsubaya, 1988; Matsubaya and Kubota, 1988).

The purpose of this paper is to summarize 


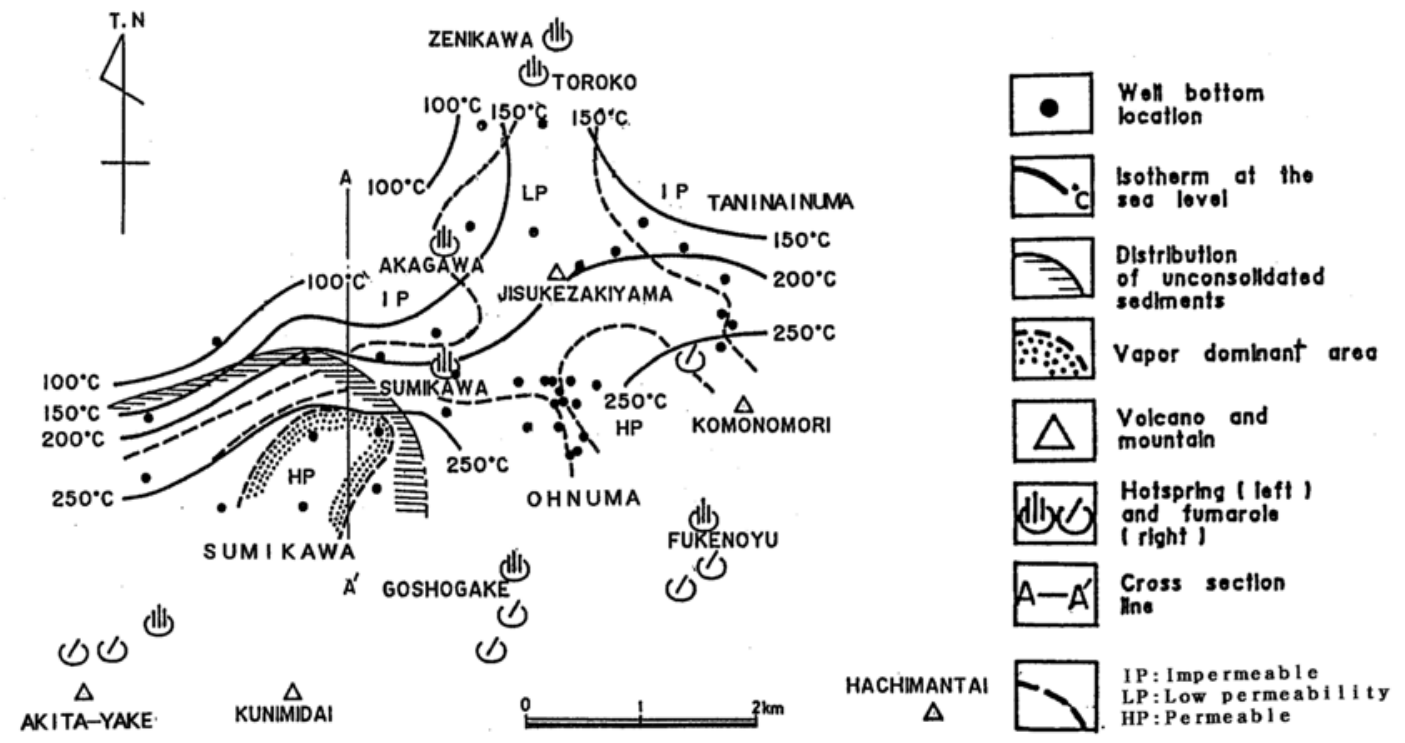

Fig. 2. General features of the Ohnuma-Sumikawa geothermal area (after Kubota, 1988).

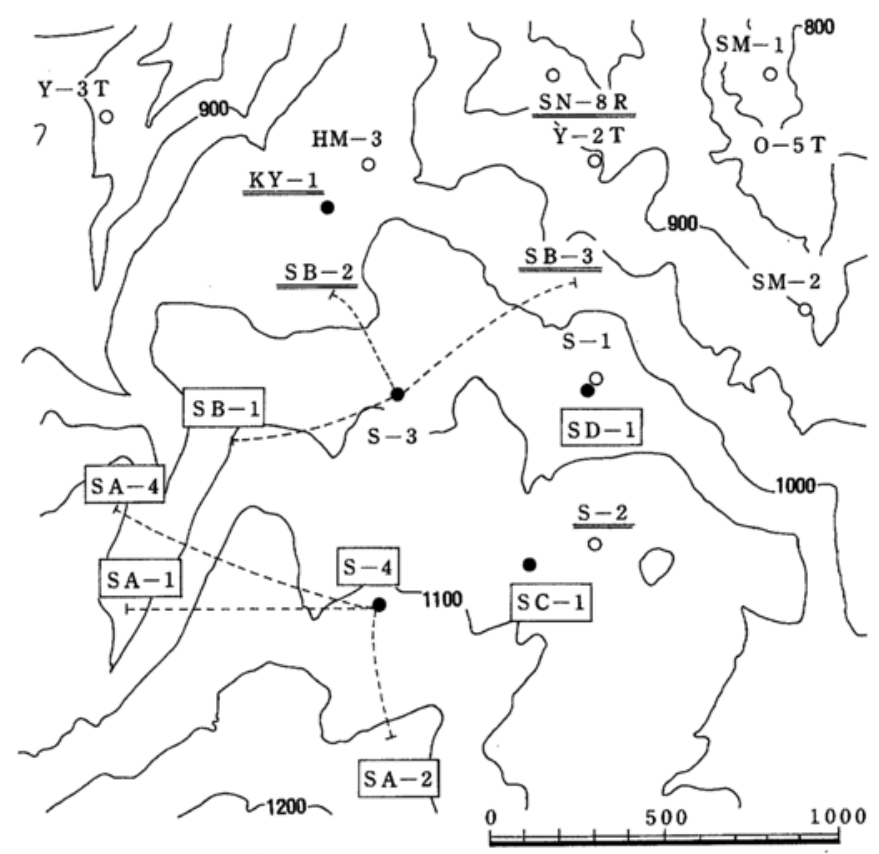

Fig. 3. Locality map of geothermal wells at Sumikawa. Production wells are labeled in boxes while reinjection wells have underlined labels. Closed circles: vertically drilled; open circles: observation wells; well tracks are shown as dashed lines. The contour interval is $50 \mathrm{~m}$.

the geochemical data of fluids discharged mainly from the newly drilled wells at Sumikawa (SA-1, SA-2, SA-4, SB-1, SD-1 and SC-1) in the Ohnuma-Sumikawa geothermal system, and to discuss the chemical characteristics of the reservoir. In this paper, the chemical composition of fluids collected in 1989 are not discussed in detail since a large quantity of river water was injected 
into all but two production wells (SD-1 and SC1) during this period. The composition of the reservoir fluid was affected by this river water injection, discussed elsewhere (Ueda et al., 1990).

\section{Outline of Geology}

To the north of the Sumikawa system, a pronounced low gravity zone is associated with an elongated north-south graben structure (Inoue and Ueda, 1965). To the south of the Sumikawa area (Fig. 1), an east-west trending volcanic chain including Mt. Akita-Yake (1366 mASL) to the west and Mt. Hachimantai $(1614 \mathrm{~m})$ to the east obscures the graben structure. Both N-S and NW-SE trending faults are assumed to occur in the Sumikawa system (MMC, unpublished).

The geology of the Sumikawa area is similar to that of the Ohnuma area (Yora et al., 1973; Sakai et al., 1986). It consists of Quaternary volcanic rocks, lacustrine sediments, and Tertiary formation (Fig. 4) intruded by granitic
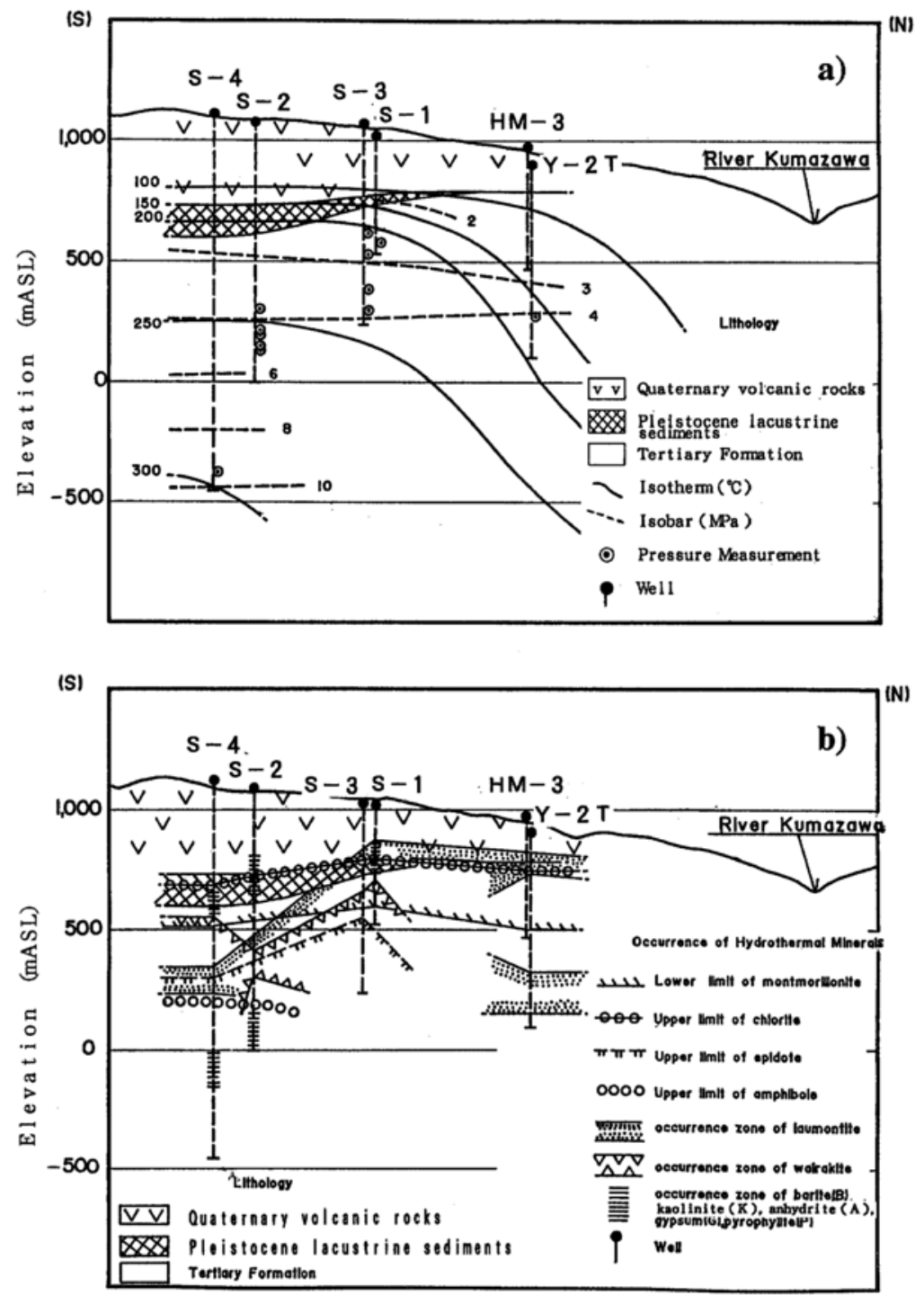

Fig. 4. Geological section of the Sumikawa geothermal system. a) Geology, and temperature and pressure profiles (after Kubota, 1986). b) Occurrence of hydrothermal minerals (after Kubota, 1986). 
rocks. The pre-Tertiary basement has not yet been reached by drilling (the deepest well at Sumikawa is $2486 \mathrm{~m}$ ). The Tertiary formation is composed of volcanic rocks and marine sediments. The deepest formation identified so far consists of granite, granodiorite and quartzdiorite intrusives into the Tertiary formation (not shown in Fig. 4). The difference from the Ohnuma area is that in Sumikawa the thick Pleistocene lacustrine sediments are overlain by Quaternary volcanic rocks. The thickness of the Quaternary lacustrine sediments increases to the southwest (Figs. 2 and 4a). Intrusive rocks are inferred to occur at greater depths beneath the area drilled at Sumikawa.

The vertical distribution of alteration minerals in the Sumikawa wells was studied by Kubota (1979, 1986), Bamba et al. (1987), Sato (1990) and MMC (unpublished data), as shown in Fig. 4b. Montmorillonite occurs above 500 mASL but is not observed in the Quaternary andesitic lavas. Chlorite is commonly found in the formation below the Quaternary rocks. Epidote occurs widely below 300 to $500 \mathrm{mASL}$ at Sumikawa but is not seen even at $0 \mathrm{mASL}$ in the lower temperature zone to the north. Amphibole exists below $200 \mathrm{mASL}$ in the high temperature zone (over $250^{\circ} \mathrm{C}$ ). Laumontite is observed to occur at random above 100 to $200 \mathrm{mASL}$ and is found locally in the Quaternary rocks. In wells with many fractures at shallow depth, laumontite occurs at a shallower depth in comparison with wells with no fractures. Wairakite exists below $600 \mathrm{mASL}$ but is not observed in the lower temperature zone; in well S-4, it is found in the high temperature zone (over $300^{\circ} \mathrm{C}$ ). In the southern part of Sumikawa, wairakite is commonly observed below the calcite zone.

A thin zone of acidic alteration coincides with the feed points of acidic fluid in well S-2 (Fig. 4b), including kaolinite, pyrophyllite, anhydrite, gypsum, barite and alunite. In general, there is a good correlation between the occurrence of temperature-sensitive minerals (Browne, 1978) and the measured temperature (compare Figs. 4a and 4b), with high temperature minerals not occurring in the colder wells to the north.

\section{Thermal STRUCTURE}

The isotherms in this area generally have the same east-west trend as the volcanic chain from Mt. Akita-Yake to Mt. Hachimantai (Fig. 2). The subsurface temperature gradually increases southward towards the volcanic chain, while it decreases sharply to the north (Fig. 2). In the high temperature region, the temperature gradient is controlled by saturation pressure conditions of a hot water column (Fig. 5a). The measured profiles deviate from the pure water curve at greater depths. This is due to the effect of $\mathrm{CO}_{2}$ in the reservoir fluid, though in some cases temperature inversions are due to incursion of cooler fluids. In Fig. 5a, the temperature profile for a boiling fluid with approximately $1 \mathrm{wt} \%$ $\mathrm{CO}_{2}$ at $300^{\circ} \mathrm{C}$ is also shown. If the $\mathrm{CO}_{2}$-bearing fluids rise and boil, $\mathrm{CO}_{2}$ is lost and the profile will more closely match that of pure water. This model is consistent with the low gas contents in the fluids at the production depths (see below).

During drilling, temperature was measured in well S-4 in a dry condition (no circulation loss); temperature increased linearly with depth (i.e., conductive) over shallow depths (above 400 mASL, not shown in Fig. 5a; MMC, unpublished data). Based on these thermal profiles, Kubota (1986) proposed the existence of convection in the high temperature zone, while conduction dominates in the lower temperature zone. The boiling temperature profiles at shallow levels in the wells (Fig. 5a) is due to heat transfer upwards in the wells under bleed conditions, and is not the natural state.

The heat source for the Ohnuma-Sumikawa geothermal system is estimated to be located under the volcanic chain to the south. The highest temperature in the area is $317^{\circ} \mathrm{C}$ at an elevation of $-840 \mathrm{mASL}$ at the bottom of well SA-2 (Fig. 5a). A thermal inversion at -1220 mASL in the deepest well, SC-1, was measured 25 weeks after an injection test, indicating deep, relatively cold water inflow.

Kubota (1986) compiled data on filling tem- 


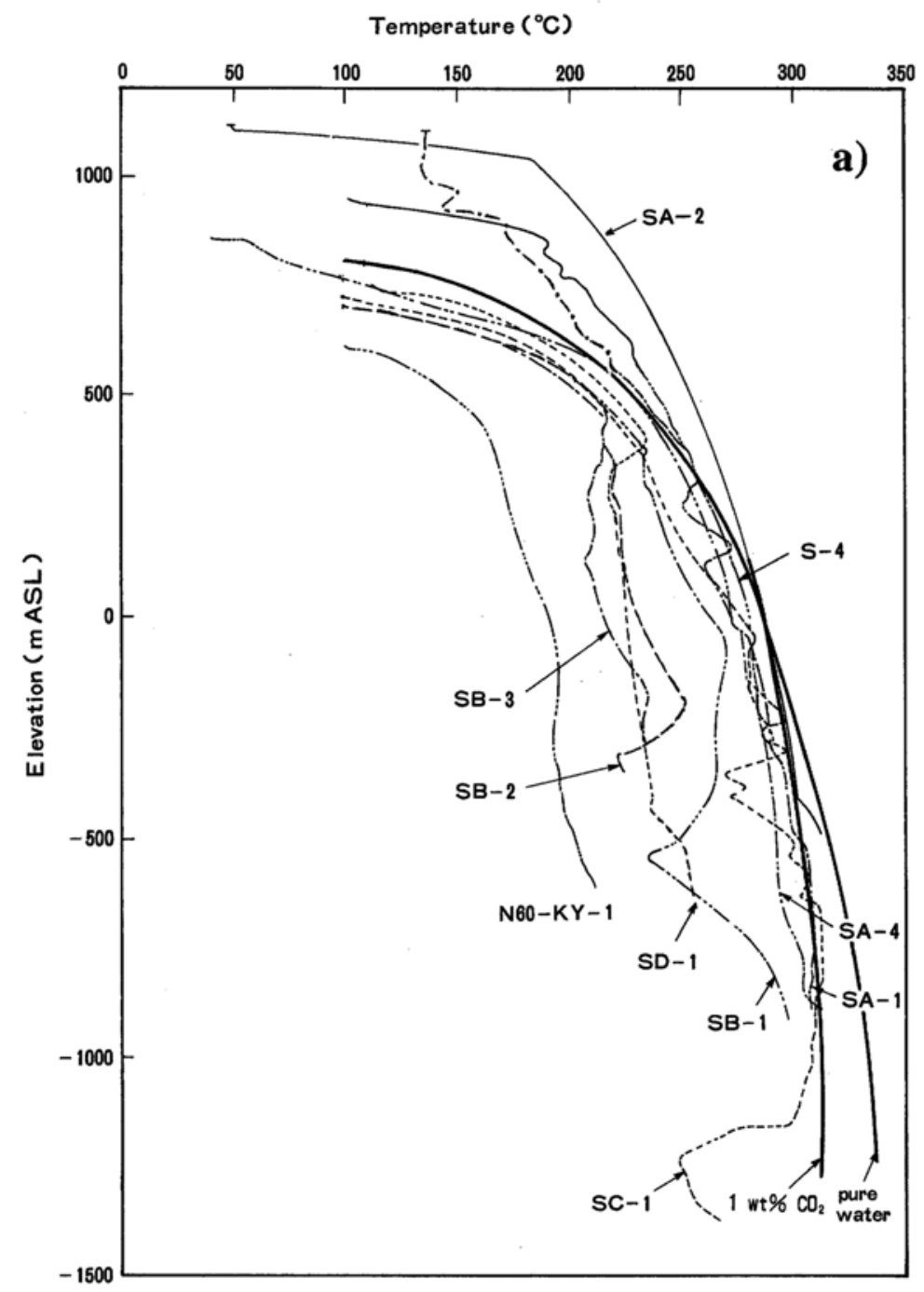

Fig. 5a. See caption with Fig. $5 b$ for explanation.

peratures of fluid inclusions in hydrothermal quartz and wairakite, and compared these data with temperature profiles of newly drilled wells. The present subsurface temperatures appears to have been constant at Sumikawa since inclusion formation, while they have decreased by several $10^{\circ} \mathrm{C}$ at Ohnuma after formation of the alteration minerals, consistent with lower temperatures (Fig. 2).

Reservoir pressure at the feedpoint of wells in three areas, Sumikawa, Ohnuma and Taninainuma in the North Hachimantai region (Fig. 2), is plotted against elevation in Fig. 4b (Kubota, 1988). Wells in the Sumikawa and
Ohnuma areas have feedpoint pressures below 400 mASL which plot near the saturated pressure profile of pure water to about -200 mASL (Fig. 5b), but above this curve (at higher pressure) at greater depth. This discrepancy may be due to a dissolved gas content of up to $1 \mathrm{wt} \%$ $\mathrm{CO}_{2}$ at higher temperatures, or in some cases to the temperature of the fluid being less than that of a pure water boiling column, as proposed before. The pressure above $400 \mathrm{mASL}$ is approximately constant at $3.1 \mathrm{MPa}$, indicating vapordominant conditions. All data for Ohnuma and Sumikawa fall on a single line (Fig. 5b), even well S-2 (issuing acidic fluid), suggesting a con- 


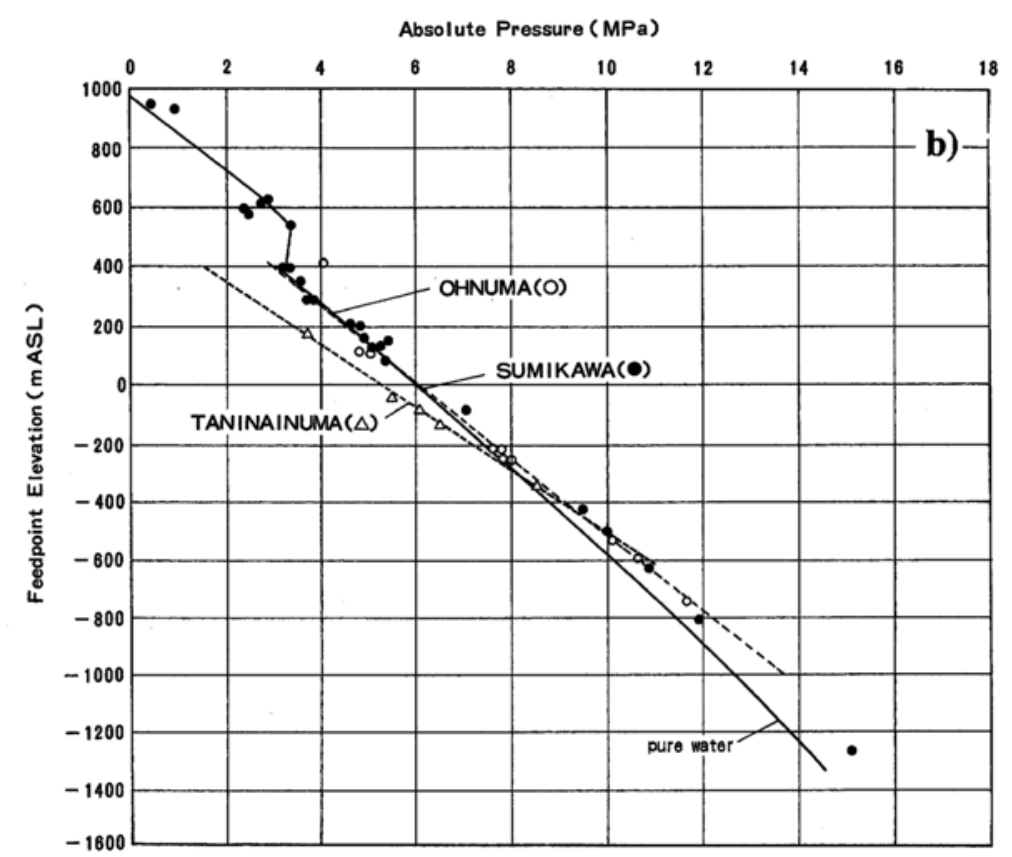

Fig. 5. Temperature and pressure profiles of the Sumikawa wells. a) Temperature profile (after MMC, unpublished data). These data are obtained at 4000 to 15000 hours after drilling. Temperature profile starts from water level for each well except for wells $S A-1$ and $S A-2$ with no data of water level. Boiling curves of pure water and containing $1 \mathrm{wt} \% \mathrm{CO}_{2}\left(a t 300^{\circ} \mathrm{C}\right)$ are also shown, drawn from the average water level. b) Pressure profile (after Kubota, 1988). Solid line shows the hydrostatic pressure of pure water.

C 1

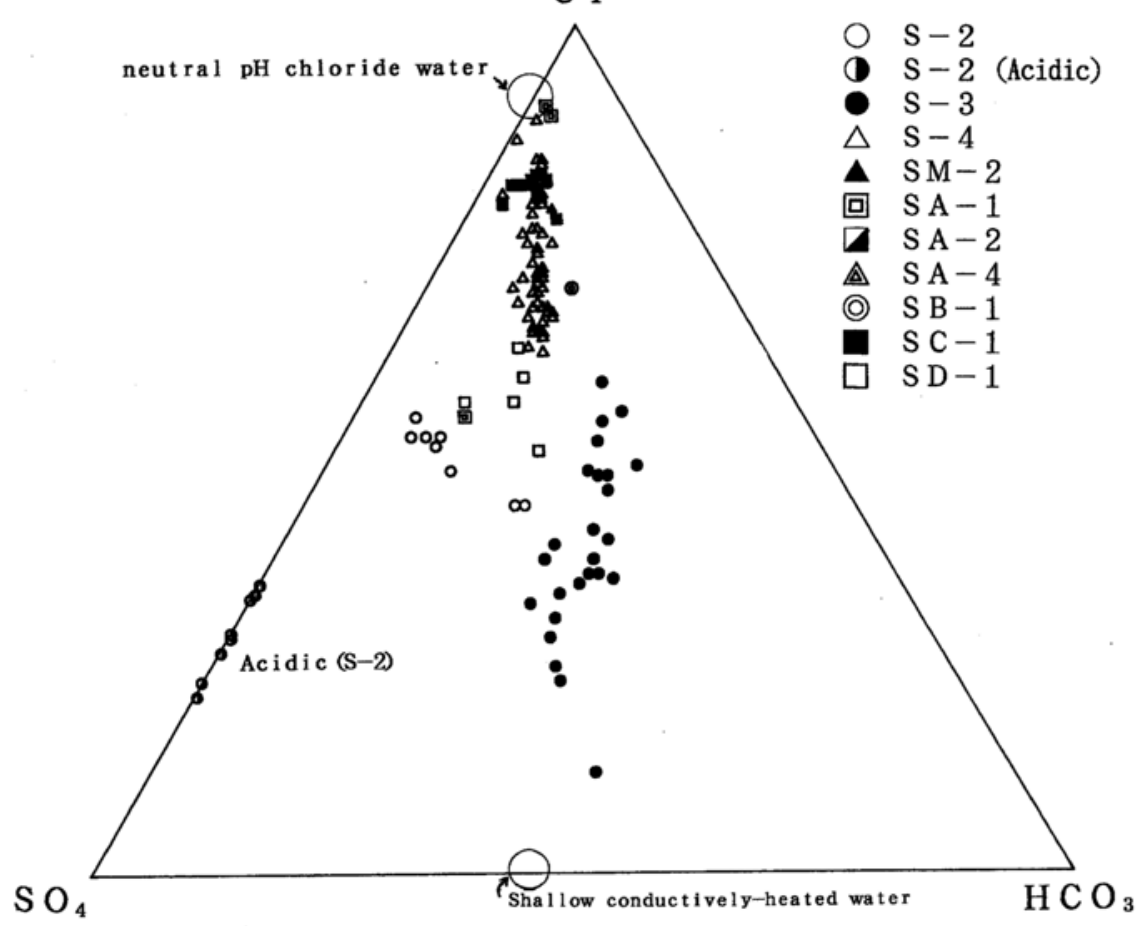

Fig. 6. $\mathrm{Cl}-\mathrm{SO}_{4}-\mathrm{HCO}_{3}$ equivalent composition of well discharges in the Sumikawa area. 
tinuous reservoir under the Ohnuma and Sumikawa areas, in contrast to the proposal of Kubota (1988). However, the Taninainuma area, to the northeast (Fig. 2), has a distinct pressure profile, indicating the reservoir is independent from Sumikawa and Ohnuma.

The upper impermeable zone acts as a caprock to the reservoir, with a high vapor/water ratio, and also acts as a barrier to prevent infiltration of cold surface water. The distribution of the impermeable zone does not correspond with any geological formation, suggesting that the impermeable zone was formed by self-sealing (Kubota, 1988).

\section{Fluid Chemistry}

Chemical data for fluids discharged from Sumikawa wells are presented in Table 1, and are plotted in Figs. 6 to 11 .

The remarkable feature of fluids discharged from the Sumikawa wells is their low total dissolved solids $(<3000 \mathrm{mg} / \mathrm{l})$ compared to other geothermal systems in Japan (e.g. 16000 $\mathrm{mg} / 1$ at Mori (Sato, 1988), $5000-8000 \mathrm{mg} / \mathrm{l}$ at Onikobe (Abe, 1988)). Also, the composition of the fluids is heterogeneous between wells. Most fluids discharged from Sumikawa geothermal wells are near neutral $\mathrm{pH}, \mathrm{Na}-\mathrm{Cl}$ type, except for fluid from well S-2 (Table 1).

The fluid discharged at different times from well S-2 can be distinguished into two groups; near neutral $\mathrm{pH}$ (though with a trend to slightly acidic conditions) and acidic chloride-sulfate types (Fig. 6). In this well, two feedpoints are recognized at 905 and $1065 \mathrm{~m}$ depth. During drilling, discharge tests were conducted separately at each feedpoint. Based on these tests, the acidic fluids issue from the deeper feedpoint, where acidic alteration minerals such as alunite and kaolinite are present (Sakai et al., 1986). Such acidic fluids are also observed at Ohnuma at depths near sea level (Sakai et al., 1986). Similar limited occurrence of deep acidic fluids within a system dominated by neutral $\mathrm{pH}, \mathrm{Na}-\mathrm{Cl}$ fluids is also reported in other geothermal systems (e.g. Hachobaru, Shimada et al., 1985; several

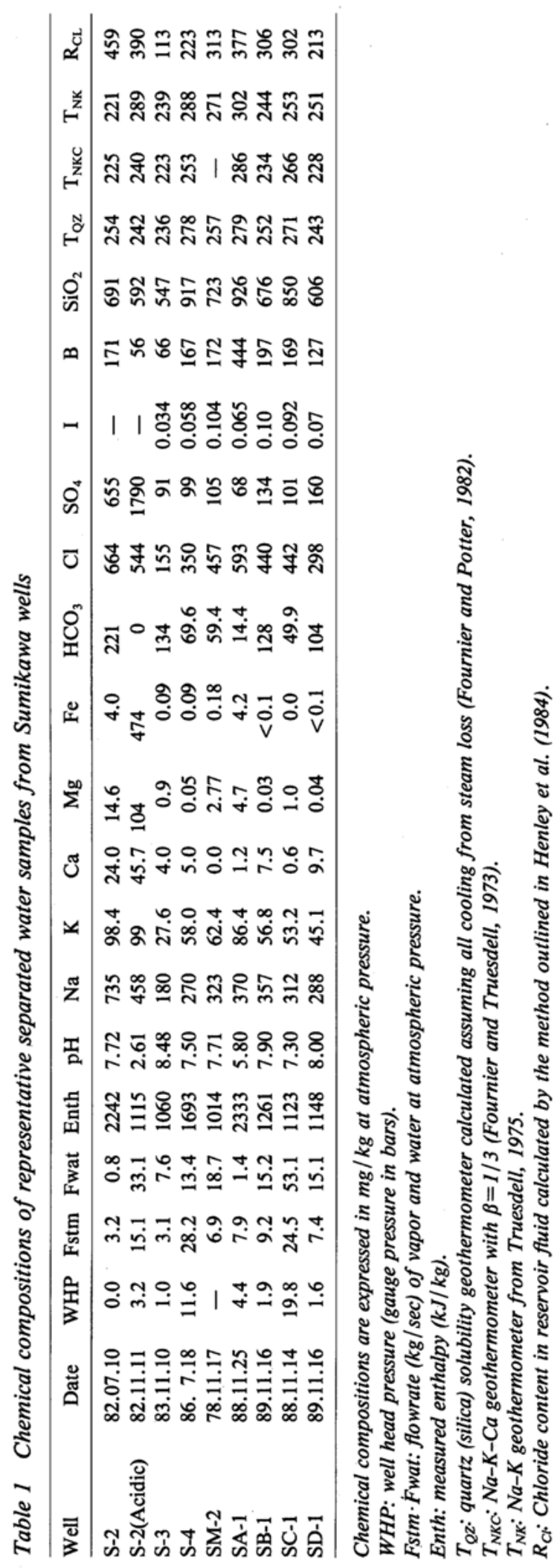




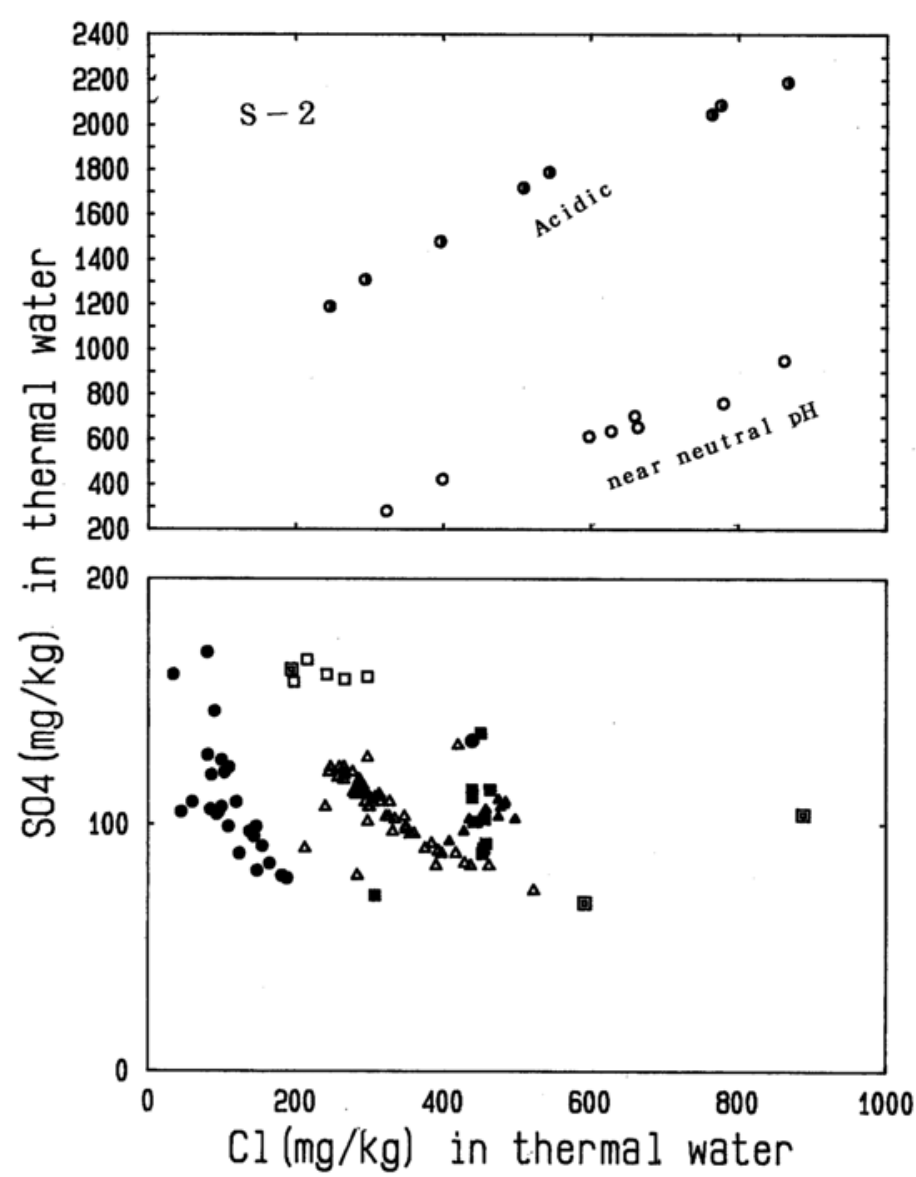

Fig. 7. $\mathrm{Cl}$ vs $\mathrm{SO}_{4}$ composition $(\mathrm{mg} / \mathrm{kg}$ ) of separated water from the Sumikawa wells. Legend as in Fig. 6.

systems in the Philippines, Reyes, 1990).

There is a good negative correlation between $\mathrm{Cl}$ and $\mathrm{SO}_{4}$ content in individual wells (Fig. 7); the $\mathrm{SO}_{4}$ content decreases with increasing $\mathrm{Cl}$ content, except for well S-2, which has a much higher sulfate concentration and shows a positive correlation with chloride. The chemical compositions (except for S-2) can be explained by mixing of two end members; deep Cl-rich water with a small amount of $\mathrm{SO}_{4}$ and a shallow water that has no chloride but a sulfate content of about $200 \mathrm{mg} / \mathrm{kg}$ plus a $\mathrm{HCO}_{3}$ component (Fig. 7). The shallow water is heated to about $200^{\circ} \mathrm{C}$, as will be discussed later (Fig. 9), by conductive heating and/or addition of steam.

Although the heating process is not yet clear, conductive heat tranfer may be dominant in the Sumikawa geothermal system due to higher tem- peratures compared with other geothermal systems (e.g., steam-heated $160^{\circ} \mathrm{C}$ water in Waiotapu, New Zealand; Hedenquist and Browne, 1989). The shallow heated water in Sumikawa is enriched in $\mathrm{SO}_{4}$ and $\mathrm{HCO}_{3}$ as mentioned above. Our experimental results of interaction between groundwater and altered andesite rocks from $\mathrm{MB}_{1}$ layer in Sumikawa show that the solution after reaction at $200^{\circ} \mathrm{C}$ has $80 \mathrm{mg} / \mathrm{kg} \mathrm{SO}_{4}$ but nil $\mathrm{Cl}\left(\mathrm{HCO}_{3}\right.$ was not analyzed) (MMC; unpublished data). This result supports the model; the shallow water was conductively heated and dissolved sulfate and carbonate from rocks during migration.

In contrast, the acidic fluid from well S-2 appears to be a mixture of a deep acid $\mathrm{Cl}-\mathrm{SO}_{4}$ water with a mixed fluid (deep chloride water plus shallow, conductively-heated sulfate-bicar- 
bonate water, Fig. 6). The sulfate-chloride water in well S-2 has two trends (Fig. 6), with one having about three times the sulfate of the other, and a $\mathrm{pH}$ of about 2 in contrast to a $\mathrm{pH}$ of 5-7 for the lower sulfate trend.

The discharge tests after drilling were usually conducted for more than 100 days, though only 10 days for wells S-1 and S-2. In well SM-2, the $\mathrm{Cl}$ content increased from 410 to $490 \mathrm{mg} / \mathrm{kg}$, whereas $\mathrm{SO}_{4}$ increased from 95 to $110 \mathrm{mg} / \mathrm{kg}$, 150 days from the start of discharge. After this period, both $\mathrm{Cl}$ and $\mathrm{SO}_{4}$ contents were almost constant (MMC, unpublished). In contrast, in well S-2, $\mathrm{Cl}$ and $\mathrm{SO}_{4}$ contents both increased with time after the start of discharge. In this well, an amount equal to only one third of the drilling fluid lost to the formation (14500 tons) was discharged (MMC, unpublished). Therefore, fluids discharged from well S-2 may have been influenced by the drilling water.

In 1989, a large volume of river water was injected into the Sumikawa production wells, and the fluids subsequently discharged have been geochemically monitored. From these results, approximately $70 \%$ of the injected water was estimated to have been discharged from well SB-1 within 50 days (Ueda et al., 1990). These results indicate that the injected surface water is not always completely discharged during later discharge tests. In this well, the $\mathrm{Cl}$ content increased with decreasing $\mathrm{SO}_{4}$ content for 5 days after the start of the post-injection discharge. After this period, both $\mathrm{Cl}$ and $\mathrm{SO}_{4}$ increased. This enrichment of $\mathrm{SO}_{4}$ shortly after the start of discharge is explained by the addition of $\mathrm{SO}_{4}$ derived from oxidation of $\mathrm{H}_{2} \mathrm{~S}$, based on isotopic evidence (Ueda et al., 1990). Fluids from well S-4 have been monitored for 7 years, with an inverse correlation between $\mathrm{Cl}$ and $\mathrm{SO}_{4}$ also observed (Fig. 7). This result strongly supports the model presented above; mixing of a deep $\mathrm{Cl}$-rich water and a shallow heated $\mathrm{SO}_{4}-$ $\mathrm{HCO}_{3}$ rich water with nil $\mathrm{Cl}$.

The quartz and alkali temperatures of the fluids studied (Fig. 8) agree within an uncertainty of about $20^{\circ} \mathrm{C}$. They vary about from $220^{\circ} \mathrm{C}$ to $320^{\circ} \mathrm{C}$ within all wells sampled, and also agree well with the measured temperature at each feedpoint (Fig. 4a). In contrast, the calculated temperature from the measured enthalpy is higher than the quartz temperature, especially in well S4 (Fig. 8b). This indicates that the fluid discharged has excess enthalpy, i.e., there are two phases at the feedpoint or vapor addition from another feedpoint (Hedenquist, 1990; Seki, 1990). The latter case is unlikely at Sumikawa because the vapor-dominant zone exists above 400ASL, where the well is sealed by casing. The fluids from well S-4 have been monitored for 6 years and the quartz and enthalpy temperatures have a tendency to increase with time.

The enthalpy and $\mathrm{Cl}$ concentration in reservoir fluid (Fig. 9) are calculated by the method outlined by Henley et al. (1984), with the enthalpy based on the quartz geothermometer temperature. Based on an intersection of the boiling (vapor gain or vapor loss) and dilution trends which envelop all data (except for well S-2 and the excess enthalpy discharges of well S-4), the parent Sumikawa geothermal fluid has a minimum temperature of about $290^{\circ} \mathrm{C}$ (slightly below the maximum measured temperature), with a $\mathrm{Cl}$ content of only $300 \mathrm{mg} / \mathrm{kg}$. This fluid either boils, or is diluted with heated water of nil chloride and a temperature of about $200^{\circ} \mathrm{C}$. This nil chloride endmember is enriched in $\mathrm{SO}_{4}$ and $\mathrm{HCO}_{3}$ (Fig. 6). The deep parent fluid is estimated to be similar to fluid from well SC-1, which has the highest flowrate of all wells $(57 \mathrm{~kg} / \mathrm{sec}(200$ tons $/ \mathrm{hrs}$ ) vapor and $86 \mathrm{~kg} / \mathrm{sec}$ (300 tons $/ \mathrm{hrs)}$ water). Fluid from well S-4 has a higher enthalpy than that from well SC-1 (Figs. 8 and 9). However, since well S-4 has discharged geothermal fluids with an excess enthalpy (which has not been corrected for), the observed trend for this well (Fig. 9) can be explained by vapor gain into deep fluids similar to those from well SC-1, and by dilution with water of nil chloride.

In this model, the representative deep fluid at Sumikawa has $\sim 300 \mathrm{mg} / \mathrm{kg} \mathrm{Cl}$ (Fig. 9). The fluid composition from all wells (except well S-2) can be explained by mixing of the deep fluid or a boiled deep fluid with shallow heated water of nil chloride and some sulfate and bicarbonate. The 

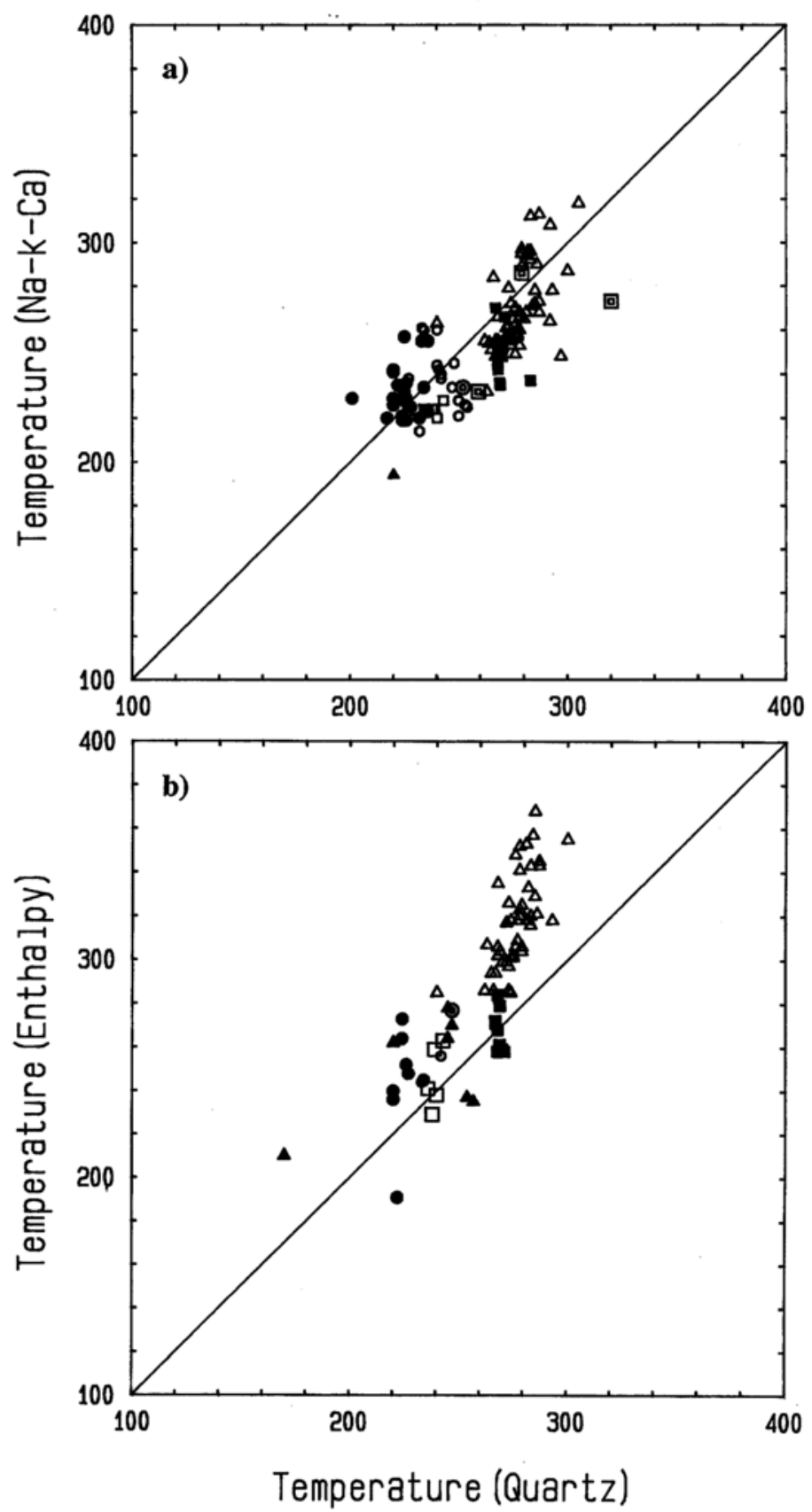

Fig. 8. Geochemical temperature of fluid from the Sumikawa wells. Legend as in Fig. 6. a) Quartz and Na-KCa temperatures. $T_{Q Z}:$ quartz geothermometer assuming maximum steam loss (Fournier and Potter, 1982). $T_{N K C}: \mathrm{Na}-\mathrm{K}$-Ca geothermometer with $\beta=1 / 3$ (Fournier and Truesdell, 1973). b) Quartz and enthalpy temperature of fluid from the Sumikawa wells. The enthalpy temperature is from the measured enthalpy at well site.

waters from both feedpoints in well S-2 have the highest chloride, though a relatively low temperature. The observed trend for well S-2 (Fig. 9) cannot be explained by a simple boiling from the deep fluid. If it is directly related to the neutral pH Sumikawa fluid, the difference may be due to multi-step boiling of the deep fluid or dilute water. Alternatively, the high $\mathrm{Cl}$ (and $\mathrm{SO}_{4}$ ) of S- 


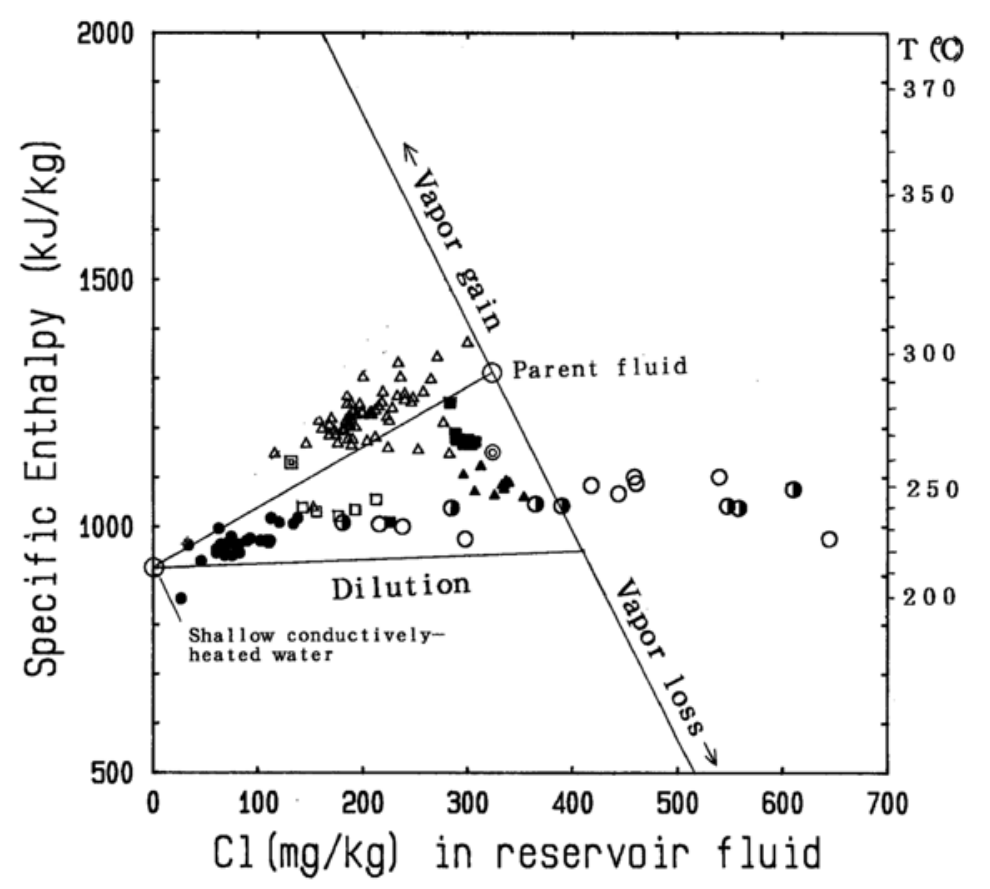

Fig. 9. Enthalpy and Cl diagram of reservoir fluid at Sumikawa. Legend as in Fig. 6. Enthalpy is calculated from the quartz solubility temperature, with $\mathrm{Cl}$ in reservoir fluid determined by the method outlined by Henley et al. (1984). The effect of excess enthalpy (e.g., S-4 discharges) has not been corrected for.

2 fluids might be due to $\mathrm{HCl}$ (and $\mathrm{SO}_{2}$ ) contribution from magmatic vapors. The similarity between the acid and neutral waters from this one well suggests that these are closely related, with the acidity neutralized by water-rock interaction.

Well SC-1 discharges the highest flowrate among the Sumikawa wells. This well is characterized by a reverse temperature profile with depth below -1000 mASL (Fig. 4a). This indicates that relatively cool water inflows at this depth (Kubota, 1988). Such cold water inflow at depth in geothermal systems is common on the margin (e.g. Youngman, 1989; Hedenquist, 1990). Reyes (1990) indicated such temperature reversals in the center of Philippine hydrothermal systems, and demonstrated down flow along faults.

\section{Fluid equilibria}

Figure 10 shows a $\mathrm{Na}-\mathrm{K}-\mathrm{Mg}$ diagram (Giggenbach, 1988) to examine the degree of chemical equilibration between the fluids and their reservoir rocks and minerals. The fluid com- positions lie on a trend from a Mg-rich component towards the full mineral-fluid equilibrium line. Most fluids are not in equilibrium with reservoir alteration minerals (e.g. feldspars, clays) that comprise the buffer curve which is plotted. In particular, the acidic $\mathrm{Cl}-\mathrm{SO}_{4}$ fluid from well $\mathrm{S}-2$ is enriched in $\mathrm{Mg}$ and is the most immature liquid at Sumikawa. Its composition is similar to that expected (Mg-rich) for andesite dissolution by acid (Fig. 10). Both the neutral to weakly acid fluid and the highly acid fluid from well S-2 plot on the same trend, indicating that the neutral to weakly acid fluid formed by neutralization of the acidic $\mathrm{SO}_{4}-\mathrm{Cl}$ fluid through simple interaction with reservoir rocks (Fig. 10) and mixing with neutral pH fluids (Fig. 6). This is independantly supported by the similar chloride-enthalpy relationship for these two fluids (Fig. 9).

Fluids from SB-1 and SC-1 plot near the full equilibrium curve (Fig. 10). These fluids represent the most mature fluid in the Sumikawa geothermal system in terms of mineral-fluid equilibrium, consistent with the model that these 


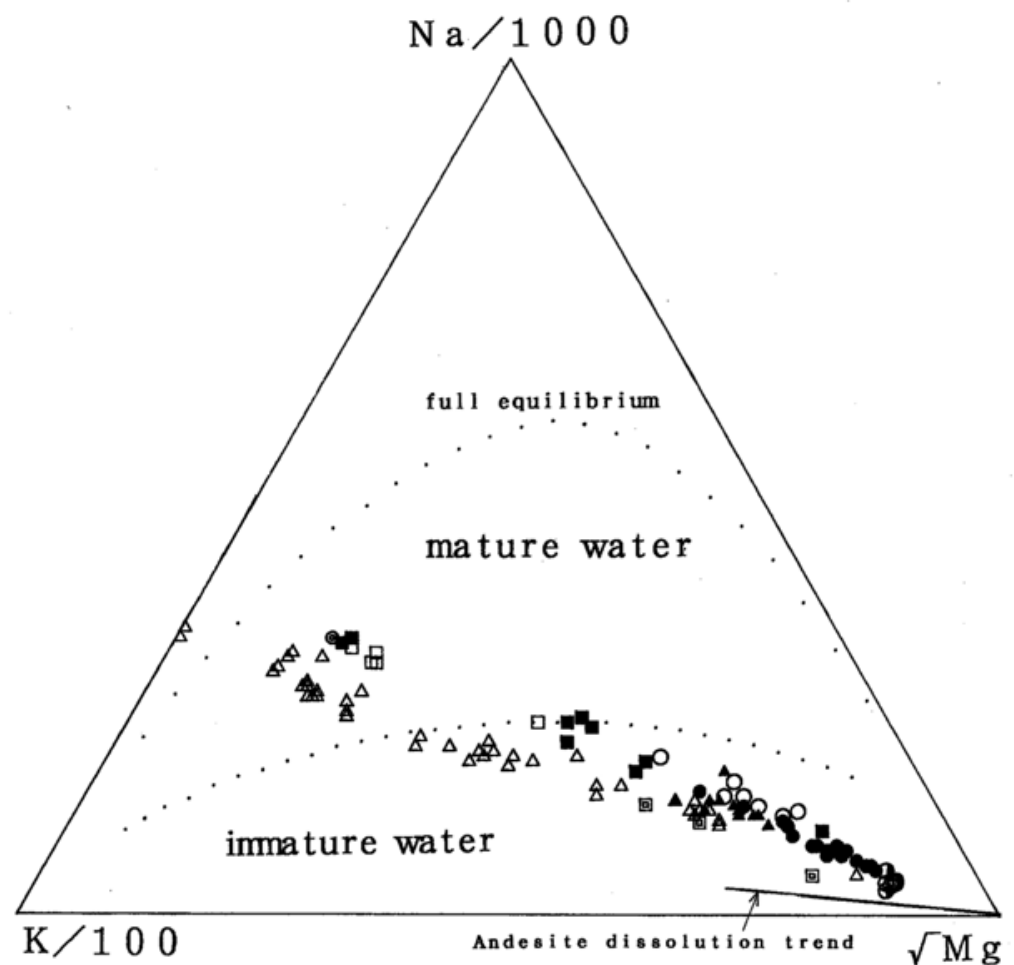

Fig. 10. $\mathrm{Na}-\mathrm{K}-\mathrm{Mg}$ diagram of separated water from the Sumikawa wells. Legend as in Fig. 6. The upper broken line is for full equilibrium conditions with feldspars and clays (Giggenbach, 1988). The region of immature water corresponds to the composition of waters related to rock dissolution without any control by mineral equilibria (Giggenbach, 1988).

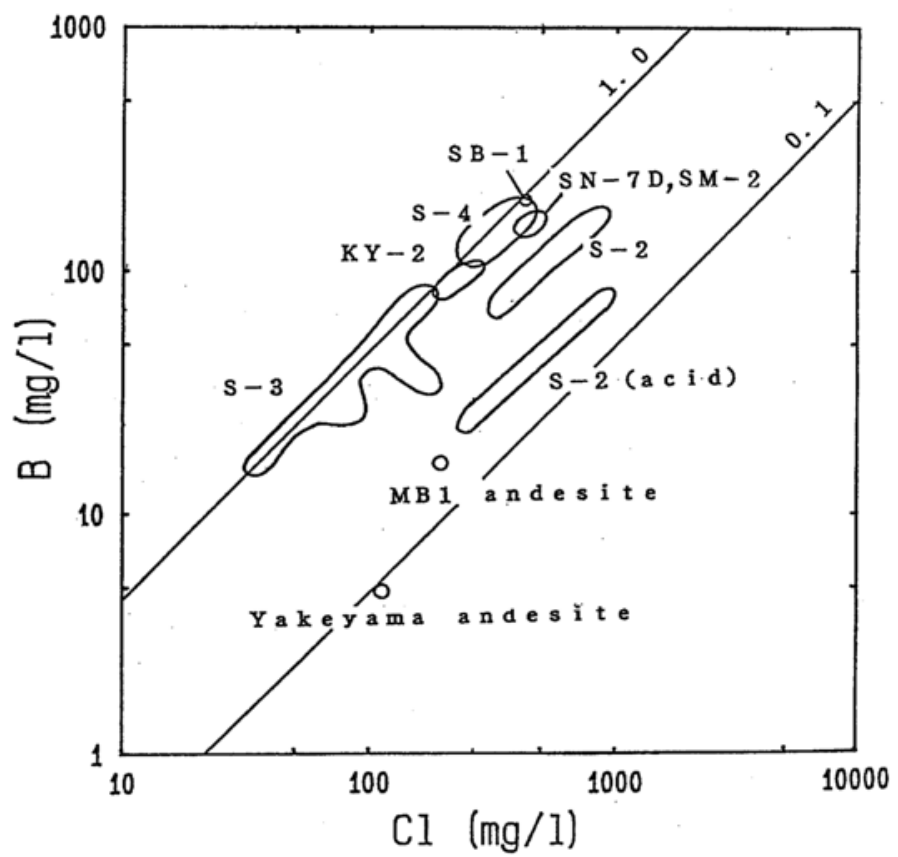

Fig. 11. B and Cl content in separated water from the Sumikawa wells. The B/Cl mole ratio is contoured. Legend as in Fig. 6. 
fluids are representative of the deep fluid at Sumikawa (Fig. 9), and supported by their isotopic compositions, described later. Therefore, the trend in Fig. 10 may be explained by dilution of the deep fluid with shallow heated water of nil chloride, in which the latter has not attained chemical equilibrium with the alteration minerals. Fluids discharged from well S-4 have been monitored over a long period. Their composition has become Mg-poor with time, shifting towards the full equilibrium line. However, the fluids collected recently are relatively enriched in $\mathrm{Mg}$. These facts indicate that the composition of reservoir fluid of well S-4 is variable and susceptible to changes with time.

One of the distinct chemical characteristics of fluids at Sumikawa is the high $\mathrm{B} / \mathrm{Cl}$ mole ratio (Fig. 11), compared with other geothermal systems in Japan (compiled in Fig. 2 of Chiba, 1991). The $\mathrm{B} / \mathrm{Cl}$ ratio of fluid from well S-2 is relatively lower than that of fluids from other wells. Especially, the ratio of the acid fluid from well S2 is the lowest of the Sumikawa wells and is almost the same as that of altered andesite from $\mathrm{MB}_{1}$ layer and Yakeyama volcanic rocks in this area (MMC, unpublished), suggesting rock dissolution (Fig. 10) may be affecting the $\mathrm{B} / \mathrm{Cl}$ ratio. On the basis of the experimental results of Ellis and Mahon (1964, 1967), Shigeno and Abe
(1983) demonstrated that the $\mathrm{B} / \mathrm{Cl}$ ratios of fluids reflect those of the reservoir rocks. The high $\mathrm{B} / \mathrm{Cl}$ ratio of most fluids at Sumikawa can be explained by a model where the fluid circulated through pre-Tertiary marine sedimentary rocks (Shigeno and Abe, 1987). In the Sumikawa geothermal system, such pre-Tertiary rocks have not been observed even in the deepest well $(2486 \mathrm{~m})$.

\section{Gas Chemistroy}

Gas compositions from the Sumikawa wells are presented in Table 2 and are plotted in Figs. 12 to 17.

The gas content varies from $0.001 \mathrm{~mole} \%$ in the reservoir fluid for a liquid feed well (such as S-4) up to $1 \mathrm{~mole} \%$ of total discharge in wells with high yapor/water ratios (such as SA-2). The total discharge composition of the excess enthalpy wells, however, will greatly over estimate the actual gas content of the liquid which is feeding the well (Seki, 1990). Figure 12 shows the $\mathrm{CO}_{2}-\mathrm{H}_{2} \mathrm{~S}-\mathrm{Rgas}$ (residual gas; not absorbed in alkaline solution) composition of fluid from Sumikawa and other geothermal systems in Japan. The data from the Japanese systems are taken from Table 1 in Chiba (1991), and Yoshida (1984). In plotting the gas data, the $\mathrm{H}_{2} \mathrm{~S}$

Table 2. Chemical compositions of representative vapor fractions from Sumikawa wells

\begin{tabular}{lllllllllllllllll}
\hline Well & Date & WHP Fstm & Fwat & Ysep & $\mathrm{G} / \mathrm{S}$ & $\mathrm{CO}_{2}$ & $\mathrm{H}_{2} \mathrm{~S}$ & $\mathrm{H}_{2}$ & $\mathrm{CH}_{4}$ & $\mathrm{~N}_{2}$ & $\mathrm{O}_{2}$ & $\mathrm{Ar}$ & $\mathrm{He}$ & $\mathrm{Ne}$ \\
\hline $\mathrm{S}-2$ & 82.07 .09 & 0 & 0.97 & 0.17 & 0.851 & 0.0007 & 74.7 & 9.9 & 2.16 & 0.49 & 9.9 & 1.8 & 0.15 & - & - \\
S-2 & 82.11 .11 & 3.2 & 4.31 & 10.7 & 0.288 & 0.0012 & 12.8 & 7.08 & 46.5 & 0.32 & 29 & 0.48 & 0.64 & - & - \\
S-3 & 83.11 .10 & 1 & 0.86 & 2.11 & 0.29 & 0.0008 & 49.7 & 25.9 & - & - & 19 & 5.2 & 0.22 & - & - \\
S-4 & 88.11 .24 & 5.58 & 21.2 & 26.8 & 0.363 & 0.00031 & 21.7 & 55.1 & - & - & - & - & - & - & - \\
SA-1 & 88.11 .04 & 5.08 & - & - & - & 0.00131 & 14.3 & 70.8 & 2.54 & 0.07 & 12 & 0.061 & 0.15 & 0.00024 & 0.00073 \\
SA-2 & 88.11 .18 & 2.27 & - & - & 1 & 0.00719 & 78.7 & 18.8 & 1.25 & 0.058 & 1.2 & 0.037 & 0.0046 & 0.00046 & - \\
SA-4 & 88.11 .13 & 2.48 & - & - & 1 & 0.0136 & 69.9 & 22.2 & 3.29 & 0.25 & 4.2 & 0.077 & 0.066 & 0.0006 & - \\
SM-2 & 78.11 .17 & 1.8 & 2.19 & 5.39 & 0.289 & 0.0003 & 48.4 & 49.9 & - & - & - & - & - & - & - \\
SB-1 & 89.10 .12 & 2.0 & 0.95 & 1.66 & 0.393 & 0.00074 & 21.7 & 16.8 & 0.355 & 0.37 & 60 & 0.59 & 0.76 & 0.00073 & 0.0011 \\
SC-1 & 88.11 .09 & 19.2 & 29.8 & 55.9 & 0.348 & 0.00074 & 22 & 16.3 & 0.447 & 0.23 & 59 & 0.22 & 0.73 & 0.00062 & 0.0011 \\
SD-1 & 89.11 .16 & 1.6 & 7.36 & 15.1 & 0.328 & 0.00089 & 34.6 & 40.6 & 1.9 & 0.27 & 22 & 0.42 & 0.3 & 0.00052 & 0.00032 \\
\hline
\end{tabular}

WHP: well head pressure (gauge pressure in bars).

Fstm $\cdot$ Fwat: flowrate $(\mathrm{kg} / \mathrm{sec})$ of vapor and water at atmospheric pressure.

Ysep: vapor fraction for gas sample.

$G / S$ : Gas/steam volume ratio.

Gas composition is expresed in volume $\%$. 


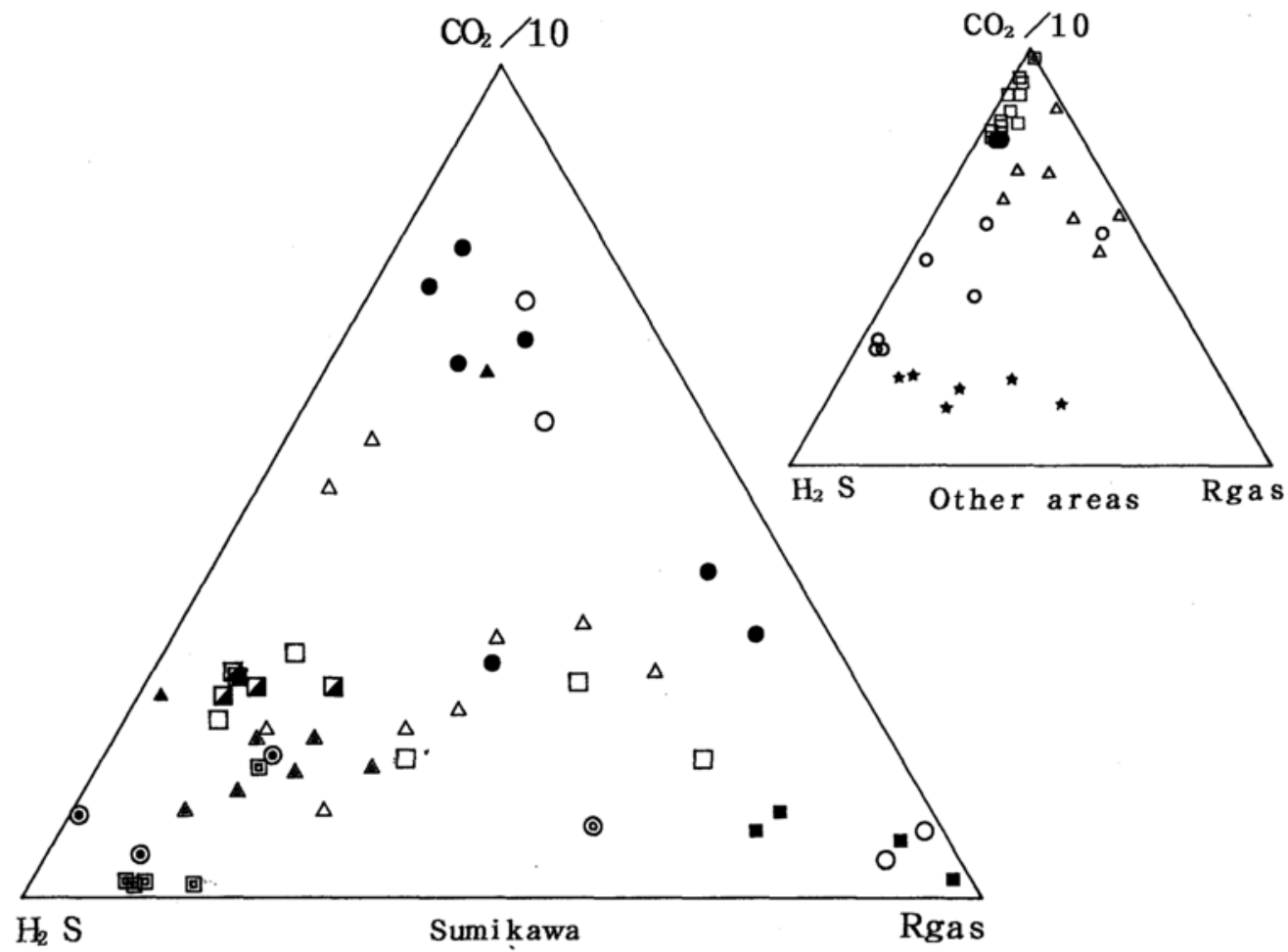

Fig. 12. Rgas- $\mathrm{H}_{2} \mathrm{~S}-\mathrm{CO}_{2}$ in vapor fraction from Sumikawa(large triangle) and other areas (inset). Symbols from the Sumikawa wells are the same as in Fig. 6 and circle with a dot means gas from the summit of Mt. Akita-Yake (MMC, unpublished data). Symbols in the inset are; square: Matsukawa, double square; Okuaizu, open circle: Kirishima, triangle: Takigami, closed star; Onikobe. These data are taken from Table I in Chiba (1991), Kiyosu (1986) and Yoshida (1984).

and Rgas contents are relatively negligible in the water fraction. However, since the amount of $\mathrm{HCO}_{3}^{-}$in the liquid phase may make a significant contribution to total $\mathrm{CO}_{2}$, the $\mathrm{CO}_{2}$ as plotted is less than the total $\mathrm{CO}_{2}$ to some extent, more so in low gas wells.

The Sumikawa fluids vary in gas components from well to well (Fig. 12), and are divided into four types; $\mathrm{H}_{2} \mathrm{~S}$-poor (S-2, S-3), Rgas-rich (SC1), $\mathrm{H}_{2} \mathrm{~S}$-rich (SA-1, SA-2, SA-4) and intermediate compositions (S-4, SB-1, SD-1). Wells S-2 and S-3 were drilled before 1985 and their feedpoints are shallower (136 and 294 mASL, respectively) than other wells (below $-150 \mathrm{mASL}$ ) except for SD-1 (215 mASL). In contrast, the feedpoint of SC-1 is the deepest $(-1228 \mathrm{mASL})$ at Sumikawa, though the temperature is lower than at shallower levels (Fig. 4a). This well was drilled in 1988 by an aerated mud drilling method. During the discharge, the Rgas component decreased with time. The $\mathrm{N}_{2}$ $\mathrm{He}-\mathrm{Ar}$ composition is similar to that of air minus oxygen (see below). Although $4 \times 10^{5}$ tons of fluid has so far been discharged from well SC1 , it is not clear whether such a high Rgas fraction is due to air dissolved in drilling fluids or due to dissolved air in the cool downflow, as mentioned before.

$\mathrm{H}_{2} \mathrm{~S}$-rich gas is characteristic of the fluids with high vapor/water ratios (Fig. 12). The Matsukawa geothermal system, $15 \mathrm{~km}$ southeast of Sumikawa, discharges vapor-dominant fluid, though the gas is enriched in $\mathrm{CO}_{2}$ (Fig. 12). $\mathrm{H}_{2} \mathrm{~S}$ rich gas is only observed in the Kirishima and Onikobe geothermal systems (Kodama and Nakajima, 1988; Kiyosu, 1986) of Japan, 


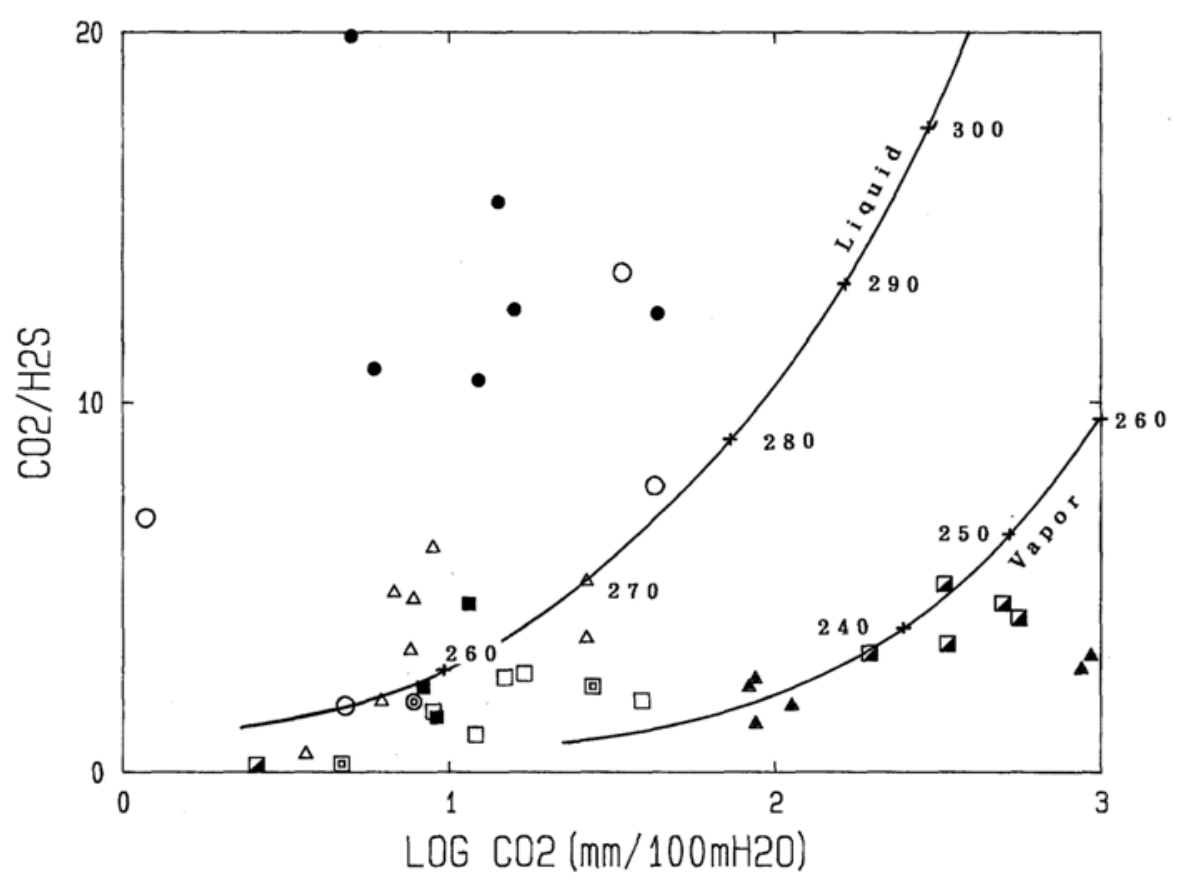

Fig. 13. $\mathrm{CO}_{2}(\mathrm{~mm} / 100 \mathrm{~m})-\mathrm{CO}_{2} / \mathrm{H}_{2} \mathrm{~S}$ ratio for total discharge compositions. Legend as in Fig. 6. Calculated liquid and vapor model curves are shown. This situation has been modelled assuming a $270^{\circ} \mathrm{Cliquid}$ of composition similar to $\mathrm{SC}-1$, with the parent $300^{\circ} \mathrm{C}$ liquid composition calculated for single step separation, as shown by Hedenquist (1990).

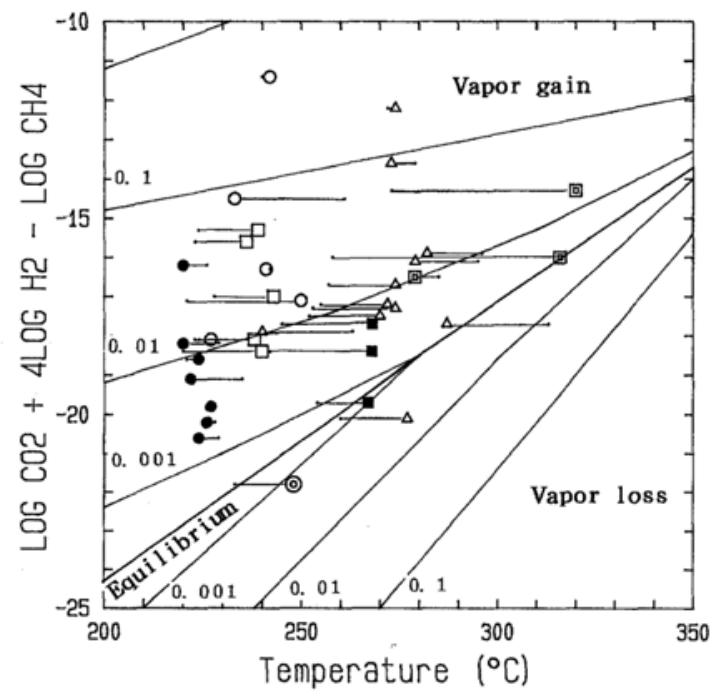

Fig. 14. Plot of temperature (of quartz (symbols) and $\mathrm{Na}-\mathrm{K}-\mathrm{Ca}$ (small dot) geothermometers) versus logarithm of the equilibrium constant for reaction (1), illustrating the effect of steam loss (boiling) and steam gain on $\mathrm{CO}_{2}-\mathrm{H}_{2}-\mathrm{CH}_{4}$ gas equilibria (Giggenbach, 1980). Legend as in Fig. 6.

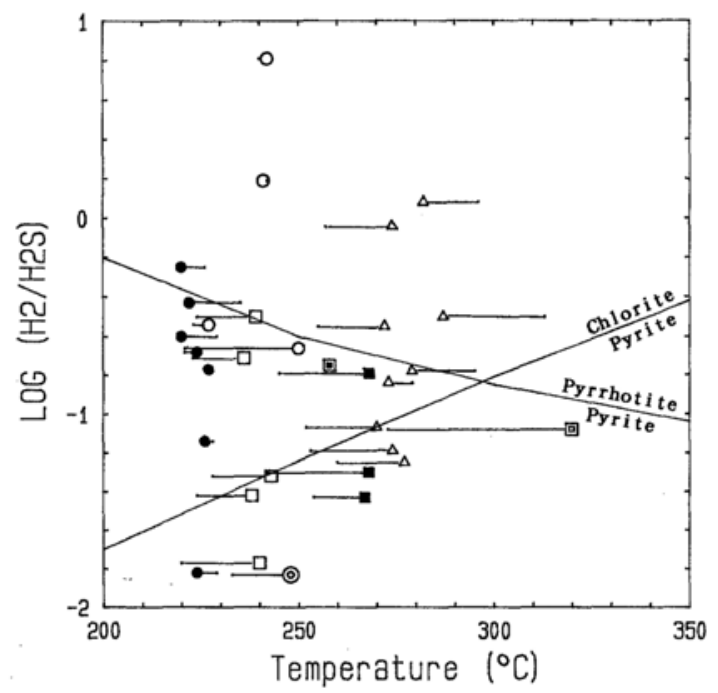

Fig. 15. Plot of temperature (of quartz (symbols) and $\mathrm{Na}-\mathrm{K}-\mathrm{Ca}$ (small dot) geothermometers) versus $\log \mathrm{H}_{2} / \mathrm{H}_{2} \mathrm{~S}$ for pyrite-Fe silicate and pyrite-pyrrhotite equilibrium (Giggenbach, 1980). Legend as in Fig. 6. 


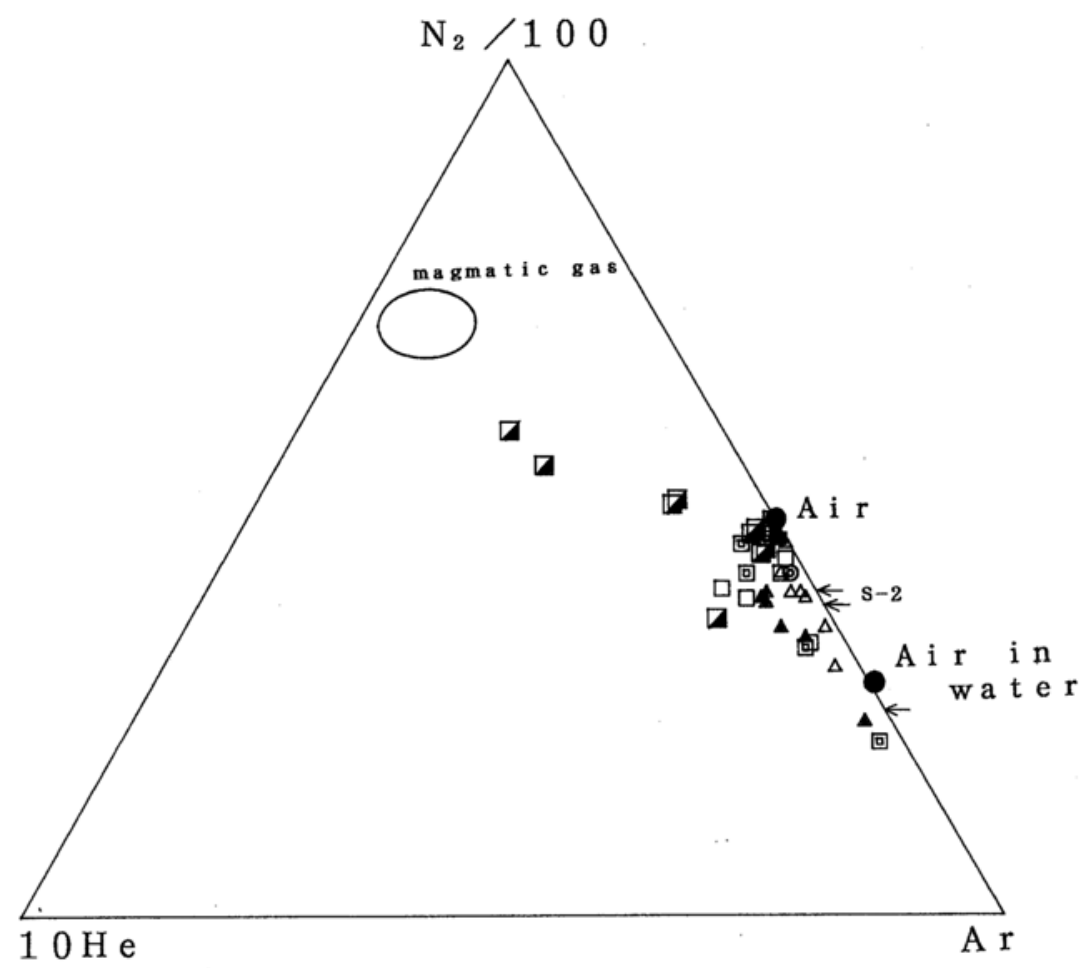

Fig. 16. $\mathrm{N}_{2}-\mathrm{He}-\mathrm{Ar}$ content of gases from the Sumikawa wells. Legend as in Fig. 6 except for closed circles indicating air and air in water. $\mathrm{N}_{2} / \mathrm{Ar}$ ratios from $\mathrm{S}-2$ are also shown by arrows. The composition of magmatic gas is defined by volcanic gases of Mt. Usu, Hokkaido, Japan (Matsuo et al., 1982).

possibly related in both cases to nearby volcanic activity. The gas from an active fumarole on the summit of Mt. Akita-Yake is also enriched in $\mathrm{H}_{2} \mathrm{~S}$ (Fig. 12).

The $\mathrm{CO}_{2}$ content in the total discharge from the Sumikawa wells is higher in fluids with high vapor/water ratios due to the preferential fractionation of gas to the vapor (Fig. 13). However, most Sumikawa gas data can be accounted for by boiling and/or a variable degree of excess enthalpy, as modelled in Fig. 13. Exceptions are wells S-2 and S-3, which are relatively depleted in $\mathrm{H}_{2} \mathrm{~S}$ (i.e., high $\mathrm{CO}_{2} / \mathrm{H}_{2} \mathrm{~S}$ ratio), compared with fluids from other wells. This may be accounted for by relatively oxidizing conditions in these wells, with $\mathrm{H}_{2} \mathrm{~S}$ converted to sulfate (and perhaps some sulfide deposition). These two wells have the highest $\mathrm{SO}_{4} / \mathrm{Cl}$ ratio of all wells in Sumikawa (Fig. 6), supporting this suggestion. Clearly, their gas compositions are distinct from the other wells.
The equilibrium constant for reaction (1) is plotted versus temperature in Fig. 14, following the method of Giggenbach (1980), with the effects of vapor gain and loss also calculated:

$$
4 \mathrm{H}_{2}+\mathrm{CO}_{2}=\mathrm{CH}_{4}+2 \mathrm{H}_{2} \mathrm{O} \text {. }
$$

The analytical quotients for gases from Sumikawa are plotted versus their quartz and $\mathrm{Na}-\mathrm{K}-\mathrm{Ca}$ geothermometer temperatures. Most data lie in the region of vapor gain, despite the fact that only wells SA-1, S-4 and SB-1 in Fig. 14 are affected by excess enthalpy conditions. This indicates that equilibrium between gases in the system $\mathrm{H}_{2} \mathrm{O}-\mathrm{H}_{2}-\mathrm{CH}_{4}-\mathrm{CO}_{2}$, according to reaction (1), has not been fully attained at Sumikawa. A similar diagram (Fig. 15) has been constructed to examine the mineral buffer control on $\mathrm{H}_{2}$ and $\mathrm{H}_{2} \mathrm{~S}$ (Giggenbach, 1980). The data have a large scatter, particularly for individual wells, with much of the scatter possibly due to variable (often high) $\mathrm{H}_{2}$. This would also ac- 


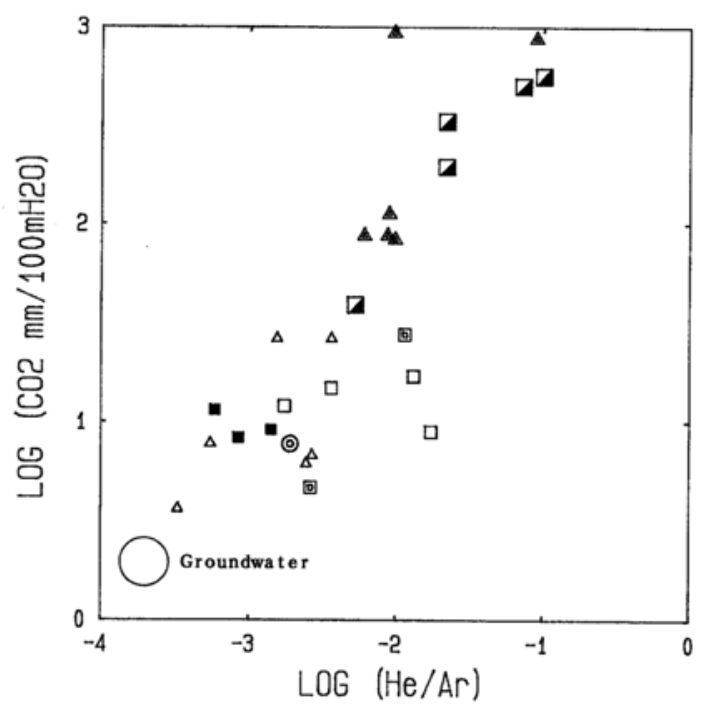

Fig. 17. $\mathrm{CO}_{2}$ content in total fluid from the Sumikawa wells and the He/ Ar ratio of the gas. The composition of groundwater is from our unpublished data. The He/Ar ratio of magmatic gas is taken to be 3.25 after Kiyosu (1985), and the $\mathrm{CO}_{2}$ composition is estimated by extrapolating the linear relation between the $\mathrm{He} / \mathrm{Ar}$ and $\mathrm{CO}_{2}$ content in the Sumikawa fluids. Legend as in Fig. 6.

count for the lack of apparent equilibrium of reaction (1). In the Sumikawa system, the fluids appear to be very immature (Fig. 10), consistent with the presence of a deep magmatic component which is only slowly being neutralized by reaction with the host rock. Such reaction would tend to produce $\mathrm{H}_{2}$ gas (including reaction of acid fluids with well casing), possibly accounting for the lack of apparent equilibrium among the gases and minerals. Such equilibrium is often noted for more "mature" geothermal systems elsewhere (Giggenbach, 1980, 1988).

\section{Gas sources}

The $\mathrm{N}_{2}, \mathrm{He}$ and $\mathrm{Ar}$ in volcanic gases in Japan are a mixture of magmatic gas and air dissolved in water (Kiyosu, 1985); the $\mathrm{N}_{2} / \mathrm{Ar}$ and $\mathrm{He} / \mathrm{Ar}$ ratios increase with increasing contribution of magmatic gas. Fig. 16 shows the $\mathrm{N}_{2}-\mathrm{He}-\mathrm{Ar}$ components from Sumikawa wells, following the presentation method of Giggenbach (1986). The results indicate that these gases are a mixture of magmatic gas and air or air dissolved in water.
Figure 16 also suggests that the magmatic gas component is larger in wells with high vapor/water ratios compared to wells with lower ratios at Sumikawa. In particular, fluid from well SA-2 has a large component of magmatic gas.

The $\mathrm{CO}_{2}$ content in the total fluid increases with increasing $\mathrm{He} / \mathrm{Ar}$ ratio of the gas (Fig. 17). This indicates that the $\mathrm{CO}_{2}$ component in the fluid is also a mixture of local meteoric water (the $\mathrm{CO}_{2}$ content is less than $50 \mathrm{mg} / \mathrm{kg}$ ) and magmatic $\mathrm{CO}_{2}$. The $\mathrm{He} / \mathrm{Ar}$ ratio of deep magmatic gas in Japan is estimated to be $\mathbf{3 . 2 5}$ (Kiyosu, 1985). Assuming this is true for Sumikawa, the $\mathrm{CO}_{2}$ content in magmatic gas feeding Sumikawa can be roughly estimated by extrapolation to be about $1 \mathrm{~mole} \%$ (Fig. 17).

\section{IsOTOPE CoMpositions}

The $\delta \mathrm{D}$ and $\delta^{18} \mathrm{O}$ values of fluids from the Sumikawa geothermal system are shown in Table 3 and Fig. 18. The isotope values of total fluids are calculated from the analyzed values and the vapor/water proportions, based on the mass flow rate ratios of vapor and separated

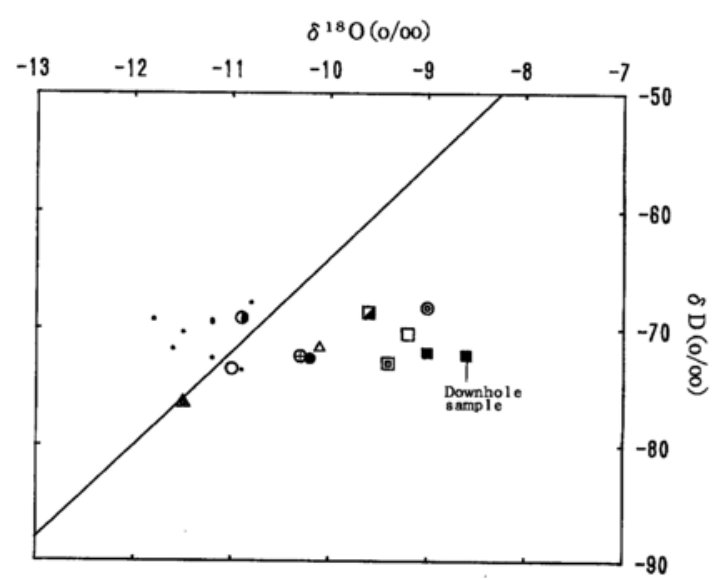

Fig. 18. $\delta D$ and $\delta^{18} O$ compositions of fluids from Sumikawa wells, calculated to total discharge values. Legend as in Fig. 6 for geotherml fluids; open circle with cross is well $S-1$. Small dots mean meteoric waters in the north Hachimantai region (MMC, unpublished). The straight line is the meteoric water line in this region $\left(\delta D=8 \delta^{18} \mathrm{O}+17\right.$; Matsubaya et al., 1983). 
Table 3. Isotopic composition of fluids from the Sumikawa geothermal system

\begin{tabular}{|c|c|c|c|c|c|c|c|c|c|}
\hline \multirow[b]{2}{*}{ WELL } & \multirow[b]{2}{*}{ Sampling Date } & \multicolumn{2}{|c|}{ WATER } & \multicolumn{2}{|c|}{ VAPOR } & \multicolumn{2}{|c|}{ TOTAL FLUID } & \multirow{2}{*}{$\begin{array}{c}{ }^{3} \mathrm{H} \\
\text { (TR) }\end{array}$} & \multirow{2}{*}{$\begin{array}{l}\mathrm{SO}_{4} \\
\delta^{34} \mathrm{~S} \\
(\% 0)\end{array}$} \\
\hline & & $\begin{array}{c}\delta \mathrm{D} \\
(\% 0)\end{array}$ & $\begin{array}{c}\delta^{18} \mathrm{O} \\
(\% 0)\end{array}$ & $\begin{array}{c}\delta \mathrm{D} \\
(\% 0)\end{array}$ & $\begin{array}{c}\delta^{18} \mathrm{O} \\
(\% 00)\end{array}$ & $\begin{array}{c}\delta \mathrm{D} \\
(\% 0)\end{array}$ & $\begin{array}{c}\delta^{18} \mathrm{O} \\
(\% 0)\end{array}$ & & \\
\hline S-1 & 82. 4.28 & - & - & -72.3 & -10.3 & -72.3 & -10.3 & - & - \\
\hline S-2 & 82. 7. 9 & -48.3 & -5.8 & -78.4 & -12.0 & -73.4 & -11.0 & - & +16.4 \\
\hline S-2(Acidic) & 82.11 .3 & -61.8 & -9.5 & -87.5 & -14.6 & -69.1 & -10.9 & - & +16.4 \\
\hline S-3 & 83. 7.28 & -65.6 & -8.8 & -89.7 & -13.8 & -72.5 & -10.2 & - & +10.2 \\
\hline S-4 & 88.11 .24 & -65.9 & -8.7 & -76.1 & -11.2 & -71.6 & -10.1 & - & +15.1 \\
\hline SA-1 & 88.11 .25 & -60.7 & -6.6 & -75.0 & -9.9 & -72.9 & -9.4 & - & +15.0 \\
\hline SA-2 & 89.10 .27 & - & - & -68.6 & -9.6 & -68.6 & -9.6 & - & - \\
\hline SA-4 & 89.11 .15 & - & - & -76.4 & -11.5 & -76.4 & -11.5 & - & - \\
\hline SB-1 & 89.11 .16 & -58.7 & -6.9 & -83.7 & -12.6 & -68.2 & -9.0 & $0.49 \pm 0.08$ & +8.8 \\
\hline SC-1 & 88.11. 9 & -66.5 & -7.6 & -82.2 & -11.5 & -72.0 & -9.0 & $0.39 \pm 0.08$ & +14.0 \\
\hline SD-1 & 89.11 .16 & -62.0 & -7.3 & -87.7 & -12.9 & -70.4 & -9.2 & $0.59 \pm 0.08$ & +14.9 \\
\hline
\end{tabular}

Isotopic composition of total fluid is calculated by a mass balance of vapor and water and their flow rates.

Tritium content is expressed in Tritium ratio and the error is $\pm 1 \sigma$.

$\delta^{34} S$ of sulfate in separated water is also shown.

water. Although the data scatter due to the uncertainty of the mass flow rates, it is clear that the $\delta^{18} \mathrm{O}$ value of the total fluids is up to $2 \% 0$ enriched in ${ }^{18} \mathrm{O}$ compared to local meteoric waters, similar to that observed in other geothermal systems in Japan (e.g., Otake; Mizutani, 1972). The fluids from well SC-1 and SB-1 are most enriched in ${ }^{18} \mathrm{O}$, and the isotopic compositions from other wells can be explained by dilution of the fluids from wells SC-1 with meteoric waters (Fig. 18) according to the relationship between the $\delta^{18} \mathrm{O}$ and $\mathrm{Cl}$ contents (Tables 2 and 3). These results are consistent with the observed features in Figs. 9 and 10. The isotopic composition of fluids collected at depth of two feedpoints $(-1900$ and $-2300 \mathrm{~m}$ ) from well SC-1 are similar, averaging -72.2 and $-8.6 \%$ in $\delta \mathrm{D}$ and $\delta^{18} \mathrm{O}$, respectively. These values are nearly the same as the calculated value for total discharge from well $\mathrm{SC}-1$ (Fig. 18). The enrichment of ${ }^{18} \mathrm{O}$ in the deep fluid at Sumikawa is mainly due to the oxygen isotope shift during water-rock interaction, as demonstrated for other geothermal systems in the world (e.g., Craig, 1963). Despite evidence for other components having a magmatic source, the water appears to be dominantly meteoric in origin.

The $\delta^{34} \mathrm{~S}$ values of $\mathrm{SO}_{4}$ in fluids from the Sumikawa geothermal system are $+14 \pm 1 \%$, ex- cept for well SB-1 (Table 3). Takahashi and Noda (1987) showed that the $\delta^{34} \mathrm{~S}$ value of $\mathrm{SO}_{4}$ increases from -2 to $+25 \%$ with increasing $\mathrm{SO}_{4}$ concentration in thermal waters from the north Hachimantai volcanic area. This tendency is also reported in the Okiura, Ikarigaseki and Yunosawa geothermal systems, $80 \mathrm{~km}$ north of Hachimantai (Muraoka and Ueda, 1991). Sakai and Matsubaya (1974) studied $\delta^{34} \mathrm{~S}$ and $\delta^{18} \mathrm{O}$ values of $\mathrm{SO}_{4}$ in thermal waters from the Green Tuff region in Japan, and found that the $\mathrm{SO}_{4}$ is a mixture of supergene $\mathrm{SO}_{4} \quad\left(\delta^{34} \mathrm{~S}=\sim-2 \%\right.$, $\delta^{18} \mathrm{O}=\sim 0 \%$ ), derived from oxidation of $\mathrm{H}_{2} \mathrm{~S}$, with fossil marine $\mathrm{SO}_{4}$ in the formation $\left(\delta^{34} \mathrm{~S}=+22 \pm 2 \%, \quad \delta^{18} \mathrm{O}=+10 \pm 2 \%\right)$. Similar results are also observed in other geothermal systems in Japan (e.g., Hakone; Matsuo et al., 1985).

In the Hachimantai area, the $\delta^{34} \mathrm{~S}$ values of $\mathrm{SO}_{4}$ in neutral Na-Cl type thermal waters increase with increasing $\delta^{18} \mathrm{O}$ values, while the $\delta^{34} \mathrm{~S}$ of $\mathrm{SO}_{4}$ in the acid sulfate thermal waters is almost constant despite a variable $\delta^{18} \mathrm{O}(\mathrm{M}$. Takahashi, H. Shigeno and T. Noda, unpublished). This indicates that the $\mathrm{SO}_{4}$ in the $\mathrm{Na}-\mathrm{Cl}$ type thermal waters here is also a mixture of supergene and fossil marine $\mathrm{SO}_{4}$. In contrast, the $\mathrm{SO}_{4}$ in the acid $\mathrm{SO}_{4}$ type thermal waters is formed by oxidation of $\mathrm{H}_{2} \mathrm{~S}$, with the $\delta^{18} \mathrm{O}$ value 
later modified by an isotopic exchange reaction with water, assisted by the fact that the rate of isotopic exchange increases with decreasing $\mathrm{pH}$ (Chiba and Sakai, 1985).

In the Sumikawa geothermal wells, the $\delta^{34} \mathrm{~S}$ values of $\mathrm{SO}_{4}$ in separated fluids are almost constant $(+14 \pm 1 \% 0)$, independent of variation in the $\mathrm{SO}_{4}$ content of fluids (MMC, unpublished). This demonstrates that the $\mathrm{SO}_{4}$ came from leaching of sulfate in the reservoir rocks, which is essentially a mixture of supergene and marine $\mathrm{SO}_{4}$ as discussed above, independent of the deep- $\mathrm{Cl}$ fluid and the shallow heated $\mathrm{SO}_{4-}$ $\mathrm{HCO}_{3}$-rich fluids.

The $\delta^{34} \mathrm{~S}$ and $\delta^{18} \mathrm{O}$ values of $\mathrm{SO}_{4}$ from the Ohnuma wells and well S-4 deviate from the tendency of simple leaching of a mixture of supergene and marine $\mathrm{SO}_{4}$; the $\delta^{18} \mathrm{O}$ value is relatively depleted in ${ }^{18} \mathrm{O}\left(\delta^{34} \mathrm{~S}=+11 \sim+16 \%\right.$, $\delta^{18} \mathrm{O}=-4 \sim-2 \%$; M. Takahashi, H. Shigeno and T. Noda, unpublished). If isotopic exchange occurs completely between $\mathrm{SO}_{4}$ and fluid in the reservoir $\left(\delta^{18} \mathrm{O}=-9 \pm 1 \%\right.$; Fig. 18$)$ at 200 to $300^{\circ} \mathrm{C}$, the $\delta^{18} \mathrm{O}$ value of the $\mathrm{SO}_{4}$ should be -4 to $0 \%$, based on the isotope fractionation factor (9 to 5\%; Lloyd, 1968; Mizutani and Rafter, 1969), respectively. This result is in good agreement with the observed $\delta^{18} \mathrm{O}$ value. According to Chiba and Sakai (1985), the half-life of the oxygen isotope exchange reaction between $\mathrm{SO}_{4}$ and water is 40 days to 100 years in neutral $\mathrm{pH}$ fluid at $300^{\circ} \mathrm{C}$ and $200^{\circ} \mathrm{C}$, respectively. This suggests that the residence time of the $\mathrm{SO}_{4}$ in the reservoir at Ohnuma and Sumikawa should be more than several tens of years. These results indicate that, in contrast to the acid sulfate waters, the $\mathrm{SO}_{4}$ in the neutral $\mathrm{pH}$ fluids from the OhnumaSumikawa geothermal system is leached from a mixture of supergene and fossil marine $\mathrm{SO}_{4}$ in volcanic rocks, with the $\delta^{18} \mathrm{O}$ values then equilibrating with fluids in the reservoir. Therefore, the $\mathrm{SO}_{4}$ in the neutral $\mathrm{pH}$ fluids is related to circulation of the meteoric system, and is not simply derived from a magmatic component. The magmatic contribution to the system is local, confined mainly to well S-2.

The tritium ratios of the fluids from the
Ohnuma-Sumikawa wells are lower than the analytical detection limit $(<0.3 \mathrm{TR})$, except for fluids collected earlier during discharge, whereas those of meteoric waters in this region are approximately 10 TR (MMC, unpublished data). As mentioned before, the fluids from the Ohnuma-Sumikawa geothermal wells are of meteoric origin. Therefore, the residence time is estimated to be more than 100 years on the assumption that the system is closed. These results support the view that the $\delta^{18} \mathrm{O}$ values of $\mathrm{SO}_{4}$ in fluids from the Ohnuma-Sumikawa wells are in equilibrium with the fluids in the reservoir.

\section{Conclusions}

The geochemical characteristics of the Sumikawa geothermal system include the notably low salinity compared to other Japanese geothermal systems, and the chemical variation from well to well. The neutral $\mathrm{pH}$ fluids are derived from a deep fluid $(\sim 300 \mathrm{mg} / \mathrm{kg} \mathrm{Cl})$ or a boiled deep fluid diluted with relatively shallow heated water that contains sulfate but nil chloride. Most fluids from Sumikawa are not in equilibrium with reservoir alteration minerals. The waters are essentially of meteoric origin, though there appears to be a magmatic contribution to the volatiles, and maybe to the deep acid $\mathrm{Cl}-\mathrm{SO}_{4}$ fluids. The fluids from Sumikawa are immature based on all indicators of chemical equilibria, probably due to the youth of system and the magmatic flux of volatiles. In particular, the magmatic component to the system is localized, with most of the $\mathrm{SO}_{4}$ in the neutral $\mathrm{pH}$ fluids derived from leaching of a mixture of supergene and fossil marine $\mathrm{SO}_{4}$ in the meteoricdominated system. Thus, the magmatic components are superimposed on a steady-state meteoric convection cell.

Acknowledgments-We thank Dr. J. Hedenquist for his encouragement through this study and for his critical reading of this paper. Thanks are due to $Y$. Sakai and members of Central Research Institute and Geothermal Energy Development Department of Mitsubishi Materials Corporation for their assistance and critical comments. We also thank Drs. Takahashi, 
Shigeno and Noda of the Geological Survey of Japan for permission to use their unpublished data. Comments by Dr. Takahashi are acknowledged.

\section{REFERENCES}

Abe, M. (1988) Onikobe geothermal power plant. Geothermal Fields and Geothermal Power Plants in Japan, Int. Symp. Geotherm. Energy, Kumamoto and Beppu, Japan, 49-56.

Bamba, M., Hatakeyama, K., Katoh, H., Kizawa, Y. and Ozeki, T. (1987) Thermal histoy at North Hachimantai Yakeyama area from geothermal alteration and fluid inclusion thermometry. Abst. Annual Meeting of Japan Geotherm. Soc. C5.

Browne, P. R. L. (1978) Hydrothermal alteration in active geothermal fields. Ann. Rev. Earth Planet. Sci. 6, 229-250.

Chiba, H. and Sakai, H. (1985) Oxygen isotope exchange rate between dissolved sulfate and water at hydrothermal temperatures. Geochim. Cosmochim. Acta 49, 993-1000.

Chiba, H. (1991) The aqueous and gas chemistry of Japanese thermal waters. Geochem. J. 25, 335-355 (this issue).

Craig, H. (1963) The isotopic geochemistry of water and carbon in geothermal areas. Nuclear Geology in Geothermal Areas (Tongiori, E. ed.), Pisa Italy, Consiglio Nazionale delle Ricerche, Laboratorio de Geologia Nucleare, 17-53.

Ellis, A. J. and Mahon, W. A. J. (1964) Natural hydrothermal systems and experimental hotwater/rock interactions (part I). Geochim. Cosmochim. Acta 28, 1323-1357.

Ellis, A. J. and Mahon, W. A. J. (1967) natural hydrothermal systems and experimental hotwater/rock interactions (part II). Geochim. Cosmochim. Acta 31, 519-538.

Fournier, R. O. and Truesdell, A. H. (1973) An empirical $\mathrm{Na} / \mathrm{K} / \mathrm{Ca}$ geothermometer for natural waters. Geochim. Cosmochim. Acta 37, 1255-1275.

Fournier, R. O. and Potter, R. W. (1982) A revised and expanded silica (quartz) geothermometer. Geotherm. Resourc. Counc. Bull. 11, 3-12.

Giggenbach, W. F. (1980) Geothermal gas equilibria. Geochim. Cosmochim. Acta 44, 2021-2032.

Giggenbach, W. F. (1986) The use of gas chemistry in delineating the origin of fluids discharged over the Taupo Volcanic Zone. Proc. Int. Volc. Congress, Session V, Auckland, 47-50.

Giggenbach, W. F. (1988) Geothermal solute equilibria: Derivation of $\mathrm{Na}-\mathrm{K}-\mathrm{Mg}-\mathrm{Ca}$ geoindicators. Geochim. Cosmochim. Acta 48, 26932711.
Hedenquist, J. W. (1990) The thermal and geochemical structure of the Broadlands-Ohaaki geothermal system, New Zealand. Geothermics 19, 151-185.

Hedenquist, J. W. and Browne, P. R. L. (1989) The evolution of the Waiotapu geothermal system, New Zealand, based on the chemical and isotopic composition of its fluids, minerals and rocks. Geochim. Cosmochim. Acta 53, 2235-2257.

Henley, R. W., Truesdell, A. H. and Barton, P. B. Jr (1984) Fluid mineral equilibria in hydrothermal systems. Reviews in Economic Geology 1, 267p.

Inoue, T. and Ueda, R. (1965) On the Hanawa fault, Akita, Japan. J. Min. Coll. Akita Univ. Ser. A. III, 15-29.

Kiyosu, Y. (1985) Variations in $\mathrm{N}_{2} / \mathrm{Ar}$ and $\mathrm{He} / \mathrm{Ar}$ ratios of gases from some volcanic areas in Northeastern Japan. Geochem. J. 19, 275-281.

Kiyosu, Y. (1986) Origin of geothermal fluid in the Onikobe area. Chikyu-Kagaku (Geochemistry) 20, 59-68 (in Japanese with English abstract).

Kodama, M. and Nakajima, T. (1988) Exploration and exploitation of the Kirishima geothermal field. Chinetsu 25, 201-230 (in Japanese with English abstract).

Kubota, Y. (1979) Hydrothermal rock alteration in the Northern Hachimantai geothermal field. Chinet$s u$ 4, 15-31 (in Japanese with English abstract).

Kubota, Y. (1985) Conceptual model of the North Hachimantai Yakeyama geothermal area. $J$. Geotherm. Soc. Japan 7, 231-245 (in Japanese with English abstract).

Kubota, Y. (1986) Geothermal exploration in northern part of the Hachimantai-Yakeyama area. Proc. Workshop of Underground Resources, Japan Mining Soc., C-2 (in Japanese with English abstract).

Kubota, Y. (1988) natural convection system at the Onuma-Sumikawa geothermal field, northeast Japan. Proc. 10th New Zealand Geothermal Workshop, 73-78.

Kubota, Y. and Matsubaya, O. (1988) A box model of Ohnuma geothermal reservoir based on the changes in chemical and isotopic compositions of geothermal water (2). J. Geotherm. Soc. Japan 10, 170 (in Japanese with English abstract).

Kubota, Y., Hatakeyama, K., Bamba, M. and Katoh, H. (1989) Chemical changes of Ohnuma geothermal fluid since operation and related reservoir management. Chinetsu, 26, 1-20 (in Japanese with English abstract).

Lloyd, R. M. (1968) Oxygen isotope behavior in the sulfate-water system. J. Geophys. Res. 73, 60996110.

Matsubaya, O., Sakai, H. and Sasaki, A. (1975) An 
isotopic study of the hot springs in the Kuroko district and adjacent areas, Akita and Aomori Prefectures. Bull. Geol. Surv. Japan 26, 1-11.

Matsubaya, O., Etchu, H. and Komuro, S. (1983) Isotopic study of hot springs in Akita prefeture. Rept. Res. Underground Resources, Akita Univ. 48, 11-24.

Matsubaya, O. and Kubota, Y. (1988) A box model of Ohnuma geothermal reservoir based on the changes in chemical and isotopic compositions of geothermal water. J. Geotherm. Soc. Japan 10, 170.

Matsuo, S., Ossaka, J., Hirabayashi, J., Ozawa, T. and Kimishima, K. (1982) Chemical nature of volcanic gases of Usu volcano in Japan. Bull. Volcanol. 45, 261-264.

Matsuo, S., Kusakabe, M., Niwano, M., Hirabayashi, J. and Oki, Y. (1985) Origin of thermal waters from the Hakone geothermal system. Geochem. J. 19, 27-44.

Mizutani, Y. and Rafter, T. A. (1969) Oxygen isotopic composition of sulphates; Pt. 3. Oxygen isotope fractionation in the bisulphate ion-water system. New Zealand J. Sci. 12, 54-59.

Mizutani, Y. (1972) Isotopic composition and underground temperature of the Otake geothermal water, Kyushu, Japan. Geochem. J. 6, 67-73.

Muraoka, H. and Ueda, A. (1991) Hydrothermal systems in the Hakkoda geothermal fields, northeast Japan. Geol. Surv. Japan Rept. 275, 135-152 (in Japanese with English abstract).

Noda, T., Abe, K., Takeno, N. and Takahashi, M. (1987) Hydrothermal systems in the Sengan area estimated from the hydrogeochemical measurements of wells. Geol. Surv. Japan Rept. 266, 295-320.

Reyes, A. G. (1990) Petrology of Philippine geothermal systems and the application of alteration mineralogy to their assessment. J. Volcanol. Geotherm. Res. 43, 279-309.

Sakai, H. and Matsubaya, O. (1974) Isotopic geochemistry of the thermal waters of Japan and its bearing on the Kuroko ore solutions. Econ. Geol. 69, 974-991.

Sakai, Y., Kubota, Y. and Hatakeyama, K. (1986) Geothermal exploration at Sumikawa, north Hachimantai, Akita. Chinetsu 23, 281-302.

Sato, A. (1990) Geothermal activity in the Sumikawa geothermal system at North Hachimantai area. Ms. Thesis, Hirosaki Univ., 135pp.

Sato, K. (1988) Mori geothermal power plant.
Geothermal Fields and Geothermal Power Plants in Japan, Int. Symp. Geotherm. Energy, Kumamoto and Beppu, Japan, 21-25.

Seki, Y. (1990) Gas concentration in aquifer fluid proior to boiling in the Oku-aizu geothermal system, Fukushima, Japan. Geochem. J. 24, 105-121.

Shigeno, H. and Abe, K. (1983) B-Cl geochemistry applied to geothermal fluids in Japan, especially as an indicator for deep-rooted hydrothermal systems. Extended Abstracts of the 4th International Sumposium on Water-Rock Interaction, Misasa, Japan, 437-440.

Shigeno, H. and Abe, K. (1987) Conceptual hydrothermal system model for the Sengan area based on geochemistry of hot springs and fumaroles. Geol. Surv. Japan Rept. 266, 251-284.

Shimada, K., Fujino, T., Koga, A. and Hirowatari, K. (1985) Acid hot water discharging from geothermal wells in the Hachobaru geothermal field. Chinetsu 22, 276-292.

Takahashi, M. and Noda, T. (1987) Isotopic investigation of waters taken from boreholes, hot springs and surface waters in the Sengan geothermal area. Geol. Surv. Japan Rept. 266, 285-294.

Truesdell, A. H. (1975) Summary of Section IIIGeochemical techniques in exploration. Second United Nations Symposium on the Development and Use of Geothermal Resources, San Francisco. 1, liii-lxxix.

Ueda, A., Kubota, Y., Katoh, H. and Hatakeyama, K. (1990) Geochemical monitoring of surface water injected into the Sumikawa geothermal wells, norhteast Japan. Proc. 12th New Zealand Geothermal Workshop, 171-175.

Yora, M., Wakita, K. and Honda, S. (1973) Exploration of Onuma geothermal field, Northeastern Japan. Chinetsu 10, 27-44.

Yora, M., Watanabe, K., Ito, J., Wakita, K. and Kubota, Y. (1977) On the geothermal system of the northern Hachimantai area. Min. Geol. 27, 233244.

Yoshida, Y. (1984) Origin of gases and chemical equilibrium among them in steams from Matsukawa geothermal area, northeast Japan. Geochem. J. 18, 195-202.

Youngman, K. J. (1989) An interpretation of the dilution at Wairakei. Proc. 11th New Zealand Geothermal Workshop, 247-254. 